FEDERAL RESERVE BANK OF SAN FRANCISCO

WORKING PAPER SERIES

\title{
The U.S. Current Account Deficit and the Expected Share of World Output
}

\author{
Charles Engel \\ University of Wisconsin and NBER \\ John H. Rogers \\ Board of Governors of the Federal Reserve System
}

March 2006

Working Paper 2006-38

http://www.frbsf.org/publications/economics/papers/2006/wp06-38bk.pdf

The views in this paper are solely the responsibility of the authors and should not be interpreted as reflecting the views of the Federal Reserve Bank of San Francisco or the Board of Governors of the Federal Reserve System. This paper was produced under the auspices for the Center for Pacific Basin Studies within the Economic Research Department of the Federal Reserve Bank of San Francisco. 


\title{
The U.S. Current Account Deficit
}

\section{and the Expected Share of World Output}

\author{
Charles Engel \\ University of Wisconsin and NBER
}

John H. Rogers

Board of Governors of the Federal Reserve System

March 9, 2006

* Departments of Economics and Finance, University of Wisconsin, 1180 Observatory Drive, Madison, WI 537061393, USA. E-mail: cengel@ssc.wisc.edu, and Board of Governors of the Federal Reserve System, Washington, DC 20551. E-mail: john.h.rogers@frb.gov. This paper was prepared for the Carnegie-Rochester Conference Series on Public Policy, on the topic of International Trade and Globalization, November 18-19, 2005. We have greatly benefited from many discussions with David Backus, Menzie Chinn, Joe Gagnon, Jaime Marquez, Michael Palumbo and the staff at the Reserve Bank of Australia. We also thank our discussant at the conference, Olivier Blanchard, and conference participants for their observations. We especially thank Joong-Shik Kang and Jeffrey Traczynski for excellent research assistance. The views expressed in this paper do not necessarily represent those of the Board of Governors of the Federal Reserve, or the Federal Reserve System. 
The U.S. Current Account Deficit and the Expected Share of World Output

\author{
Charles Engel and John H. Rogers
}

\begin{abstract}
We investigate the possibility that the large current account deficits of the U.S. are the outcome of optimizing behavior. We develop a simple long-run world equilibrium model in which the current account is determined by the expected discounted present value of its future share of world GDP relative to its current share of world GDP. The model suggests that under some reasonable assumptions about future U.S. GDP growth relative to the rest of the advanced countries - more modest than the growth over the past 20 years - the current account deficit is near optimal levels. We then explore the implications for the real exchange rate. Under some plausible assumptions, the model implies little change in the real exchange rate over the adjustment path, though the conclusion is sensitive to assumptions about tastes and technology. Then we turn to empirical evidence. A test of current account sustainability suggests that the U.S. is not keeping on a long-run sustainable path. A direct test of our model finds that the dynamics of the U.S. current account - the increasing deficits over the past decade - are difficult to explain under a particular statistical model (Markov-switching) of expectations of future U.S. growth. But, if we use survey data on forecasted GDP growth in the G7, our very simple model appears to explain the evolution of the U.S. current account remarkably well. We conclude that expectations of robust performance of the U.S. economy relative to the rest of the advanced countries is a contender - though not the only legitimate contender - for explaining the U.S. current account deficit.
\end{abstract}

JEL codes: F32, F41 


\section{Introduction}

The large U.S. current account deficits in recent years have been the subject of an enormous amount of study in academia, among government and central bank economists, in business economics reports, and in the press. ${ }^{1}$ Many different explanations of the cause of the deficit have been offered, and to varying degrees we believe that all may have played a role in the evolution of the deficit: low private saving in the U.S. generated by financial innovations or asset price inflation; large public-sector budget deficits; a "glut" of savings in the rest of the world driven by demographic factors in the rich countries and capital market imperfections in the emerging markets; and, perhaps even misalignment of the nominal exchange rate leading to excessively cheap import prices for the U.S. in the short run.

Many studies pose the question of whether the current account deficit is sustainable. However, an exact definition of "sustainable” is elusive. For example, take the simplest smallcountry model of the current account based on intertemporal optimization. Assume the country is growing over time because of productivity growth in the tradable sector, and that it faces a constant world interest rate. The country will be on a sustainable path - meaning it is not violating its budget constraint - and following an optimal path even though it runs a current account deficit in all periods, its current account deficit grows forever, its current account/GDP ratio is constant, and its debt/GDP ratio rises forever (though asymptotes). ${ }^{2}$ This suggests that there is no obvious short-cut to determining whether a country’s current account deficit is leading it into trouble, or whether its current account deficit is the outcome of optimal decisions.

Instead of trying to define "sustainable”, we ask whether there are plausible assumptions under which the U.S. current account deficit is consistent with intertemporal optimizing behavior. This type of model is probably less useful for examining higher frequency movements in trade balances, but we believe it is appropriate for examining the U.S. imbalance since adjustment is likely to take place over a long period of time. Specifically, we undertake an extended back-of-the-envelope exercise that begins by assuming that households in the U.S. have a relatively high intertemporal elasticity of substitution (unity). We then embed the U.S. in a general equilibrium model of the world economy. We derive the simple and intuitive insight that

1 See, for example, Backus et. al. (2005), Bernanke (2005), Blanchard et. al. (2004), Caballero, et. al. (2005), Chinn (2005), Clarida et. al. (2005), Edwards (2005), Faruqee, et. al. (2005), Gourinchas and Rey (2005), Kouparitsas (2005), Kraay and Ventura (2005), Obstfeld and Rogoff (2000, 2004, 2005), and Truman (2005).

${ }^{2}$ These results can be derived easily in a small-country model with log utility of expenditures, and a Cobb-Douglas utility over consumption of traded and non-traded goods, and with no factor mobility. 
the U.S. - or any country - optimally will run a current account deficit if the sum of its current and expected future shares of world GDP (net of investment and government spending), discounted by households' discount factor in utility, exceeds its current share of world net GDP. We undertake a series of calibration and empirical exercises to assess whether the U.S. deficit (about 7\% of net GDP in 2004, as depicted in Figure 1) can be explained plausibly by optimistic forecasts of growth in the U.S.'s future share of world net GDP. ${ }^{3}$

Figure 2 is the starting point of our analysis. It shows one of the most striking economic developments of the last 25 years: the dramatic increase in U.S. output relative to the rest of the high-income world. Specifically, the chart plots U.S. net GDP as a share of advanced-country net GDP. ${ }^{4}$ We net out government spending and investment because our theory suggests that consumption spending ultimately depends on income that is available for household consumption, but a plot of unadjusted GDP shares would look very similar. The chart also eliminates the influence of exchange rate swings by comparing real GDP growth relative to GDP shares in 1990, in a way that will be explained in greater detail later.

The striking thing about this graph is that since some time in the 1980s, the U.S. share appears as if it is on an upward linear trend. Its share has increased from a trough in 1982 of around 38\% to its level in 2004 of approximately 44\%. Prior to 1982, it appears that the U.S. share fluctuated around a level of roughly $38.5 \%$.

GDP shares capture two factors that are typically considered separately in the neoclassical approach to the current account. First, if the country's income is expected to rise, it may borrow now and run a current account deficit. Second, if the world interest rate is low, the country's incentive may be to borrow more now. One factor that may lead to lower interest rates is high saving in the rest of the world, which might in turn be generated by poor growth prospects in those countries. Our model reworks the neoclassical model to show how we can express the optimal consumption path as a function of the current and expected future discounted sum of the country's share of world net output. This representation is useful because it expresses the economic forces in a transparent and intuitive way, and it gives us a way of testing the model that does not require a measure of equilibrium long-run world real interest rates. The effects of real interest rates are implicitly captured by the "shares” model. For example, if the rest of the

\footnotetext{
${ }^{3}$ Erceg et. al. (2002), Backus et. al. (2005), Caballero et. al. (2005), and Faruqee et. al. (2005) conduct similar exercises.

${ }^{4}$ Advanced countries include the G7 plus Switzerland, Sweden, and Norway.
} 
world's income growth is expected to be slow, in the standard representation their high saving will reduce world interest rates and these low rates will discourage saving in the U.S.. In the "shares" approach, we see directly that U.S. borrowing is encouraged by low growth in the rest of the world, because that low growth will lead to higher future output shares for the U.S.. Another nice feature about the "shares" model is that it applies to countries of any size. There is no difference in the representation for countries that are too small to affect world real interest rates, and large countries that can.

In assessing whether the U.S. current account deficit is compatible with a plausible projection of the U.S.'s future share of world GDP, we have made a number of "heroic" assumptions to determine what set of countries constitute the rest of the world, what is the appropriate measure of the equilibrium real exchange rate used to calculate GDP shares, etc. We discuss these assumptions below in detail.

We find under a baseline calculation that if the U.S. share is expected to grow another 7\% (percent, not percentage points) over the next 25 years, then our model implies it is optimal to run a current account deficit that is 7\% of net GDP. In other words, Figure 2 puts the U.S. share at slightly under $44 \%$ at the end of 2004. The current U.S. deficit is then "explained" if households expect an increase in the U.S. share to $47 \%$ by the end of 2029.

The implication of the U.S. deficit for adjustment of the real exchange rate has drawn a lot of attention. We examine this by adopting a special case of our shares model. In it, each country produces a non-traded good and specializes in production of a traded good. The set-up is essentially identical to that of Obstfeld and Rogoff (2004), with two significant deviations. First, they ask what are the effects on the real exchange rate from an exogenous change in spending (or exogenous increase in output) that is sufficient to reduce the U.S. current account deficit. In contrast, we examine the adjustment of the real exchange rate along an optimal consumption path. Second, they assume in essence that factors are immobile between sectors within a country. We consider a longer-run framework that allows for inter-sectoral factor mobility within countries.

Our findings are reminiscent of Benigno and Thoenissen (2003). If U.S. growth is driven in part by productivity growth in the traded sector, there will be a tendency for the price of U.S. traded goods to fall relative to the price of foreign-produced traded goods. This is simply a supply effect. But this works toward a decline in the U.S. consumer price level relative to the 
rest of the world (a real depreciation) because of the home bias in consumption of tradable goods. On the other hand, as long as tradable/non-tradable productivity growth is greater in the U.S. than in the rest of the world, there will be an increase in the relative price of non-traded goods. This works simply through the classical Balassa-Samuelson effect. Practically speaking, the overall effect on the long-run real exchange rate may be very small, because the BalassaSamuelson effect and the home-bias effect work in opposite directions. U.S. growth in recent years has been led by productivity gains in both traded and non-traded industries. In our baseline calculation, if traded/non-traded productivity rises by a cumulative $8 \%$ greater amount in the U.S. than in the rest of the world over the next 25 years, then under the scenario in which the U.S. net GDP share rises by 7\%, there will be no change in the U.S. real exchange rate.

How plausible are these simulations? While Figure 2 is a starting point, it is almost a stopping point as well. The problem comes in choosing a model for the future U.S. share. It looks like the U.S. share is rising along a linear trend in Figure 2, but of course that cannot literally be true. Given that the upward trend must halt, Figure 2 gives no clue at all when it will come to an end, and how.

We take a few stabs at empirically assessing the model. One approach is similar to Bohn (2005), who examines the sustainability of the U.S. government budget deficit. We ask, in essence, whether there is evidence that net exports rise as the debt/GDP rises. Figure 3 shows that the answer to this question is surely no. This Figure plots the ratio of net external debt to GDP and net exports for the U.S., annually, 1790-2004. After1930, it is clear that our debt/GDP ratio is rising continuously. There seems to be no hint, on the other hand, of an improvement in net exports. While the "shares" model may be able to explain the large current account deficit/GDP ratio of the U.S. in 2004, explaining the dynamics of the U.S. current account deficit is much more difficult. The problem is in explaining the increasing deficit. The model says that if a country expects its world share of GDP to rise, it will run a large deficit initially, but its primary trade deficit will shrink over time (as its debt/GDP ratio rises.) That is not consistent with Figure 3.

A second empirical approach is to estimate the shares model on the data in Figure 2. We model the shares as following a Markov-switching process between two AR(1) regimes. We cannot let the data determine the mean in the second regime. Fitting an AR(1) to post-1982 data produces an autoregressive coefficient greater than one, implying the share is explosive. Instead, 
we impose a mean. We try various values greater than the maximum observed in the data. The idea is that Figure 2 may imply that the U.S. share is converging post-1982, very slowly, to some high value such as $47 \%$.

This model is also not successful in explaining the dynamics of the U.S. current account. The model can account for the level of the deficit in 2004. The problem is that the assumptions on future growth in U.S. shares that can explain the level in 2004 would imply that the U.S. deficit should have been even larger in earlier years. Even with Bayesian updating about the probability that we have moved from the state that prevailed in 1975-1982 (in which the mean U.S. share was about 39\%) to the new state with the high long-run share that we impose for the post-1982 data, our model implies that the U.S. should have relatively quickly digested the good news about future U.S. net GDP shares. The U.S. should have been running big deficits even earlier.

That finding reflects the fact that consumption is front-loaded in the neoclassical model. If there is good news about future output, the model implies an immediate rise in consumption. So from the perspective of the shares model, the puzzle is not so much why the U.S. deficit is large as why has it been rising?

We suggest possible reasons for slow adjustment, and explore one of those possibilities that markets systematically underestimated U.S. growth relative to the rest of the world. Here, we use evidence from surveys of economic forecasters. For the period 1993-2004, we can construct measures of expected future shares of G7 output for the U.S. Using these measures for expectations, we find that the "shares" model does a remarkably good job of explaining the evolution of the U.S. current account.

Of course, it is possible that something else has driven the recent rise in the U.S. current account deficit. The obvious alternative that has been emphasized in many studies is the effect of tax cuts in the U.S. Our model incorporates Ricardian equivalence. In our model, tax cuts do not reduce national saving. But, indeed, tax cuts might be the explanation for the path of the U.S. current-account deficit after 2000. Our conclusions section notes this, and some other possible factors that could influence the current account that are not incorporated in our model. 


\section{The "Shares" Model of the Current Account}

We build a two-country general equilibrium model in which households choose consumption optimally over an infinite horizon. We begin with the case in which households in each country discount future utility by the same factor, $\beta$, and utility of aggregate consumption is logarithmic (implying a unitary intertemporal elasticity of substitution.) We examine the model under the assumption of perfect foresight.

\section{2.a Equal Discount Factors, Log Utility}

We normalize the number of households in each country to equal one, but we allow the number of individuals in each household to be different in the home and foreign country. If preferences are homothetic, we can write a household's total nominal expenditure on consumption as $P_{t} C_{t}$, where $P_{t}$ is the exact consumer price index, and $C_{t}$ is the real consumption bundle for the representative household. We have $C_{t}=N_{t} c_{t}$, where $c_{t}$ is per person consumption, and $N_{t}$ the number of people per household in the home country. $Y_{t}^{V}$ is the total nominal value of output in the home country, net of investment and government spending. (The superscript $V$ dentoes “value”.) The corresponding variables for the foreign country are labeled with a *. ${ }^{5}$

We have not assumed that preferences are identical between the home and foreign country. A household could, for example, have a home bias in consumption, in which it gives greater weight in preferences to goods produced in its own country. There could be nontraded goods, so that only home-country households consume home-country nontraded goods, and likewise for foreign households. All that we require is that preferences be homothetic, so that we can define consumption aggregates for each household and their exact price index.

We can write the budget constraint for each household in the home country as:

$$
P_{0} C_{0}+\frac{P_{1} C_{1}}{R_{1}}+\frac{P_{2} C_{2}}{R_{1} R_{2}}+\ldots=R_{0} B_{0}+Y_{0}^{V}+\frac{Y_{1}^{V}}{R_{1}}+\frac{Y_{2}^{V}}{R_{1} R_{2}}+\ldots
$$

\footnotetext{
${ }^{5}$ The model we examine is one in which only real values are determined. It is helpful to maintain the notion that prices are expressed in terms of a currency, because then the symmetry between the home and foreign country will be clearer. But we should interpret all nominal prices as being expressed in a common currency, as if these two countries were in a currency union. To reiterate, this is merely notational convenience, and has no implications for the results in the model.
} 
Here, $R_{t}$ is the nominal gross interest rate for period $t . B_{t}$ is the home country's nominal claims on the foreign country at time $t$ (so that if the home country is a debtor, $B_{t}$ is negative.) The Euler equation for consumption is given by: ${ }^{6}$

$$
\frac{P_{t+1} c_{t+1}}{P_{t} c_{t}} G=\beta R_{t+1} .
$$

$G$ is the gross population growth rate, $G \equiv \frac{N_{t+1}}{N_{t}}$, which we assume is constant. We can then write the Euler equation in terms of aggregate consumption:

$$
\frac{P_{t+1} C_{t+1}}{P_{t} C_{t}}=\beta R_{t+1} .
$$

Note that equation (2) does not depend on the growth rate of population. An analogous equation holds for the foreign country, even if its population growth rate is different from home's. In other words, our model allows for differential population growth rates.

From equation (2) and its foreign counterpart, we get:

(3) $Y_{t+1}^{W}=Y_{t+1}^{V}+Y_{t+1}^{* V}=P_{t+1} C_{t+1}+P_{t+1}^{*} C_{t+1}^{*}=\beta R_{t+1}\left(P_{t} C_{t}+P_{t}^{*} C_{t}^{*}\right)=\beta R_{t+1}\left(Y_{t}^{V}+Y_{t}^{* V}\right)=\beta R_{t+1} Y_{t}^{W}$.

We have used the equilibrium condition that the total value of world consumption is equal to the total value of world output (net of investment and government spending.) We use the notation $Y_{t}^{W}$ to denote the value of world net output at time $t$.

It follows that

(4) $\quad R_{t}=\frac{Y_{t}^{W}}{\beta Y_{t-1}^{W}}$.

Substituting equations (2) and (4) into (1), we get:

$$
\left(\frac{1}{1-\beta}\right) P_{0} C_{0}=R_{0} B_{0}+Y_{0}^{W}\left(\gamma_{0}+\beta \gamma_{1}+\beta^{2} \gamma_{2}+\ldots\right) \text {. }
$$

Here, $\gamma_{t} \equiv \frac{Y_{t}^{V}}{Y_{t}^{W}}$ is the home country's share of world net GDP at time $t$. We can slightly rewrite this equation, and express nominal consumption at time $t$ as:

\footnotetext{
${ }^{6}$ This is the Euler equation when the objective is to maximize the discounted sum of current and future utility of per capita consumption.
} 


$$
P_{t} C_{t}=(1-\beta) R_{t} B_{t}+(1-\beta) \frac{Y_{t}^{V}}{\gamma_{t}}\left[\gamma_{t}+\beta \gamma_{t+1}+\beta^{2} \gamma_{t+2}+\ldots\right]
$$

This equation says that the consumption output ratio for a country will depend on the discounted sum of its current and future share of world net GDP, relative to its current share. That is, define the present value relationship:

$$
\Gamma_{t} \equiv(1-\beta)\left[\gamma_{t}+\beta \gamma_{t+1}+\beta^{2} \gamma_{t+2}+\ldots\right]
$$

Then write (6) as:

$$
\frac{P_{t} C_{t}}{Y_{t}^{V}}=(1-\beta) \frac{R_{t} B_{t}}{Y_{t}^{V}}+\frac{\Gamma_{t}}{\gamma_{t}} .
$$

Equation (8) indicates that the home country will have a high ratio of current consumption to output when its expected discounted current and future share of world net GDP, $\Gamma_{t}$, is high relative to its current share of world net GDP, $\gamma_{t}$. The interest rate does not discount future income in equation (8), because it has been solved out. The interest rate at any time depends on the growth rate of world net output, according to equation (4). The relationship in equation (8) could be consistent with any world growth rate. That is, what matters for the country's consumption/output ratio is its current and expected future shares of world output. The higher its future share of world output compared to its current share, the greater its consumption/output ratio. That is true whether its share of world output is rising because its own output is rising faster than the rest of the world's output is rising, or it is falling less quickly than the rest of the world's output is falling.

We derive a current account equation by using the national income accounting identity, $Y_{t}^{V}=P_{t} C_{t}+N X_{t}$, where $N X_{t}$ is the home country's net export of goods and services (not including interest payment on its debt.) We can rewrite equation (6) as:

$$
Y_{t}^{V}-N X_{t}=(1-\beta) R_{t} B_{t}+(1-\beta) \frac{Y_{t}^{V}}{\gamma_{t}}\left[\gamma_{t}+\beta \gamma_{t+1}+\beta^{2} \gamma_{t+2}+\ldots\right] \text {. }
$$

The current account is given by $C A_{t}=N X_{t}+\left(R_{t}-1\right) B_{t}$. We propose the following approximation: $C A_{t} \approx N X_{t}+(1-\beta) R_{t} B_{t}=N X_{t}+\left(R_{t}-\Upsilon_{t}^{W}\right) B_{t}$, where $\Upsilon_{t}^{W} \equiv \frac{Y_{t}^{W}}{Y_{t-1}^{W}}$. That is, our approximation to the current account is smaller than the true current account by $\left(\Upsilon_{t}^{W}-1\right) B_{t}$. (This term is zero if the world growth rate is zero.) With this approximation, we can then write 


$$
C A_{t}=Y_{t}^{V}\left(1-\frac{\Gamma_{t}}{\gamma_{t}}\right)
$$

or, $z_{t} \gamma_{t}=\gamma_{t}-\Gamma_{t}$, where $z_{t} \equiv \frac{C A_{t}}{Y_{t}^{V}}$. We use this relationship in our simulations.

It is easy to infer from equation (10) what the dynamics of current account adjustment will look like. Consider a country whose share of world net GDP is growing. The share cannot

grow without bound. So, if $\frac{\Gamma_{t}}{\gamma_{t}}>1$ at some time $t$, then at some point in the future, $\frac{\Gamma_{t+j}}{\gamma_{t+j}}$ must decline. A country that is expecting growth in its future share of world net GDP will run a current account deficit today, but its current account deficit/GDP will decline in the future. If the home country's growth exceeds the growth in the rest of the world, home consumption increases immediately. The home country borrows from the foreign country. Over time, home and foreign consumption grow at equal rates - equal to the growth rate of net world GDP.

We have derived this under perfect foresight, but in the data we look for a relationship between the current account and expected future income shares. We simply take the short-cut of putting an expectation directly into $(10)^{7}$ :

$$
z_{t} \gamma_{t}=\beta \gamma_{t}-(1-\beta) E_{t}\left[\beta \gamma_{t+1}+\beta^{2} \gamma_{t+2}+\ldots\right] \text {. }
$$

Equation (11) implies a relationship between a country's current account relative to world net GDP $\left(z_{t} \gamma_{t}\right)$ and the country's current and expected future shares of world net GDP. We note that it is neither GDP per capita nor some measure of productivity that is relevant for this calculation. What matters is aggregate GDP net of investment and government spending. The U.S.'s GDP has been rising relative to the rest of the advanced countries in part because its workforce has been increasing. Immigration, a higher birth rate, and more working hours per year all contribute to the rise in the U.S. share of advanced-country output.

\section{2.b Heroic Assumptions}

We use this model to assess whether the very large U.S. current account deficits could potentially be consistent with plausible expectations about the future growth in the U.S. share of

\footnotetext{
${ }^{7}$ If we had derived the model under the assumption of uncertainty, then equation (11) would not hold exactly. So (11) is not, strictly speaking, derived from the Euler equation under uncertainty and the rest of the model. Perhaps future work can assess the error involved with the approximations used to derive (11).
} 
“world” GDP. In both our simulations and empirical work, we use output shares as measured in Figure 2 as the basis for our comparisons.

We view our model as being a long-run equilibrium model, but we believe that there are short- and medium-run fluctuations in key economic variables that are not captured in our model. Most importantly, our model calls for measuring GDP at world prices. That is, the U.S. share of world GDP should be measured as the value of its GDP divided by the value of world GDP, in nominal terms. But there are large swings in real exchange rates that do not represent long-run equilibrium movements. How do we calculate equilibrium real exchange rates for purposes of calculating GDP shares?

We considered several ways of smoothing the wide swings in U.S. real exchange rates: moving averages over 5-year windows, HP-filtering, quadratic detrending, etc. Ultimately, none of these were entirely satisfactory. Without filtering the real exchange rate at all, the U.S. share shows an upward trend (as Figure 2 does) but its movements are dominated by real exchange rate swings. Bilateral real exchange rates have swung by 30-, 40-, or 50-percent over spans of two or three years. Because the effects of the real exchange rate can be so large in the short run, the choice of filter also has a large effect on the short- and medium-run measurement of shares.

Our decision was simply to measure GDP at constant real exchange rates, thus eliminating all effects of real exchange rate movements. That is, we assume that long-run purchasing power parity holds among advanced countries. We made that choice in part because there is to some degree consensus that long-run PPP does hold among these countries. For example, Rogoff's (1996) well-known survey states, “at long last, a number of recent studies have weighed in with fairly persuasive evidence that real exchange rates ... tend toward purchasing power parity in the long run” (p. 647.) Also, as we have noted, our model of real exchange rates (set out below in section 3) actually implies that under plausible assumptions the equilibrium real exchange rate will not move very much even if the U.S. GDP share grows significantly.

We use 1990 real exchange rates to measure GDP in each country for all years. In 1990, the U.S. real exchange rate was approximately at its mean level over the period of our analysis (1975-2004) relative to the other 9 countries in our study. We then measure output shares using 
real output for each year, converted into common units using the 1990 real exchange rate. Our measure of GDP shares should match the PPP-corrected measures, and in fact it does. ${ }^{8}$

If we were calculating the U.S. share relative to a larger number of countries, the U.S. share would not have grown as dramatically (or would have fallen), using a PPP-corrected measures of GDP. But it would be misleading to conclude that the U.S. share of world GDP is falling. What we need according to the model is the U.S. share of GDP calculated at equilibrium world prices. We have assumed that equilibrium real exchange rates are constant. But that is different from assuming that equilibrium real exchange rates are constant and equal to unity for all countries - which is the assumption made in calculating PPP-adjusted GDP measures. While that assumption is reasonable when we restrict ourselves to advanced countries, it is far from true when we include low-income countries. The U.S. share of advanced country GDP was approximately the same in 1990 whether one measured GDP using actual real exchange rates or PPP-adjusted real exchange rates. The same is not true of U.S. GDP compared to GDP for lowand middle-income countries. ${ }^{9}$

Our measure of advanced country GDP is the sum of GDP for the U.S., the rest of the G7, plus Switzerland, Sweden, and Norway. Adding other advanced countries, such as Australia or smaller European countries, would not alter the picture of Figure 2. But why do we not include the larger emerging markets? Why, especially, do we not include China and the emerging economies of East Asia that have experienced rapid growth?

Even subject to the caveat that the relevant measure of these countries' GDP would be smaller than PPP-adjusted measures, including them would still make the increase in the U.S. share less dramatic than Figure 2 depicts. These rapidly growing countries should really be the big borrowers on world markets, and they should show current account deficits according to our model. Clearly our model is wrong if we try to use it to assess East Asian current accounts.

\footnotetext{
${ }^{8}$ We use our own calculations because we can calculate quarterly measures of GDP shares, but at the annual frequency our measure is nearly identical to one calculated from PPP-adjusted GDP reported by the World Development Indicator of the World Bank.

${ }^{9}$ For example, in 2004, the combined GDP of Brazil, China, India, Indonesia, Korea, Mexico, Philippines, and Thailand was 2.43 times the GDP of the U.S., when one uses PPP-adjusted measures of GDP. But at world prices, all of these countries put together have a GDP that is smaller than U.S. GDP. Their GDP is only 74.4\% percent of U.S. GDP measured at world prices. That is, their weight relative to the U.S. is reduced by a factor greater than three if GDP is calculated at world prices rather than PPP prices.
} 
But given that it is wrong for East Asia, we need to make some adjustment in applying the model to the U.S. For some reason, there is a "saving glut" in these emerging markets. Bernanke (2004) advances several hypotheses for this glut - including the notion that these countries are building up a nest egg to use in the event of another financial crisis. They are running current account surpluses, adding to world saving net of investment.

We choose to omit these countries from our analysis. We treat them as if they are neither contributing to nor drawing from the world pool of net saving. If we modeled the contribution of East Asian emerging economies to net world saving, the effect would be to lower world real interest rates and increase borrowing in the rest of the world. The U.S. has a greater incentive to borrow today because of this glut of saving from the emerging market countries.

One might argue that we are ignoring precautionary saving. Even though these emerging markets are saving today, perhaps the U.S. should be more cautious in taking advantage of low world interest rates. If the glut of saving disappeared - if the East Asian countries began acting more like our model says they should - then the U.S. might be forced to rapidly reduce its borrowing. The adjustment process could be painful. In light of this possibility, the U.S. should reduce borrowing today. It is difficult to model this effect, and we do not try. We will return to this point in the Conclusion.

Our model assumes that all borrowing and lending takes place at the same interest rate. In fact, the U.S. apparently earns a higher return on its foreign investments than it pays to foreigners who invest in the U.S. Figure 4 plots the decline in the U.S. external net asset position since 1982. Although there are serious and well-known measurement issues, the chart reproduces the conventional wisdom that the U.S. has emerged as a large debtor. But Figure 5 shows the U.S. net investment income as a share of GDP. That also has declined since 1982, consonant with the decline in the U.S. asset position. But the decline in investment income has not been nearly as sharp as the decline in the net asset position, and the chart shows that U.S. net investment income in 2004 was still positive.

Gourinchas and Rey (2004) and Lane and Milesi-Ferretti (2004) offer analyses of this phenomena. There are two reasons for the discrepancy in returns. First, the U.S. external portfolio is more heavily weighted toward direct foreign investment and equities, while foreigners' portfolio of U.S. assets is dominated by Treasury securities. That is, U.S. investors buy riskier assets that have higher average returns. Even within classes of assets, the U.S. earns 
a higher expected return on its foreign investments, and Gourinchas and Rey note that this accounts for more than half the difference in the rates of return on the portfolios. If the U.S. can always earn more on its foreign investments than foreigners earn on their investments in the U.S., then a primary deficit could be sustained forever. We do not consider the effects of the actual return differential when we assess whether the U.S. current account could be consistent with intertemporal optimization.

\section{2.c Model Simulations for the U.S. Current Account}

According to equation (11), the current account depends on the current share of world GDP, $\gamma_{t}$, compared to the expected discounted sum of current and future share of world GDP, $\Gamma_{t}$. We consider this simple autoregressive model for the home country’s net GDP share:

$$
\gamma_{t+j}=\alpha^{j} \gamma_{t}+\left(1-\alpha^{j}\right) \bar{\gamma}
$$

Then

$$
\Gamma_{t}=\frac{1-\beta}{1-\alpha \beta} \gamma_{t}+\frac{\beta(1-\alpha)}{1-\alpha \beta} \bar{\gamma}
$$

so the discounted sum of the current and future shares is a weighted average of the current share and the long-run steady-state share, $\bar{\gamma}$. The more weight that individuals put on the future in their utility (larger $\beta$ ) or the faster the convergence to the steady-state value (smaller $\alpha$ ), then the greater the importance of the long-run output share in determining current consumption.

Substituting this expression into equation (10), we get

$$
\frac{C A_{t}}{Y_{t}^{V}}=1-\left[\frac{1-\beta}{1-\alpha \beta}+\frac{\beta(1-\alpha)}{1-\alpha \beta} \frac{\bar{\gamma}}{\gamma_{t}}\right]
$$

Note that the solution for the current account to GDP ratio does not depend on the absolute value of the GDP shares, but only the ratio of the long-run to current GDP share. So, the calibration does not depend on any measure of the current U.S. share, but only on how much its share is expected to increase.

This equation can be inverted to ask what assumption about the long run increase in the

U.S. share of adjusted GDP could account for a current account/ net GDP ratio of -.06 or -.07. The ratio at the beginning of 2004 was approximately -.07. We get:

$$
\frac{\bar{\gamma}}{\gamma_{t}}=1-\frac{1-\alpha \beta}{\beta(1-\alpha)} \frac{C A_{t}}{Y_{t}^{V}} .
$$


Following usual calibrations, we will assume the annual discount factor in utility is $\beta=0.98$. If the increase in output shares is very gradual, so that $\alpha=0.95$, we find that in order to have $\frac{C A_{t}}{Y_{t}^{V}}=-.07$, we need $\frac{\bar{\gamma}}{\gamma_{t}}=1.098$. That is, if the U.S. expects a gradual $10 \%$ (not 10 percentage point) increase in its share of world GDP, then a current account to net GDP ratio of -7\% can be optimal.

That may seem like a very large increase, but it is approximately the size of the increase the U.S. has experienced over the past 20 years, according to Figure 2. If the U.S. share is going to gradually rise by this much, with an autoregressive coefficient of 0.95 , then the growth over the next 25 years in the share would need to be about 7.1\% (with an eventual cumulative growth of 9.8\%). That is, the current account/GDP ratio of -.07 is consistent with expectations that the share of U.S. net GDP will grow by 7.1\% over the next 25 years. In terms of Figure 2, this translates into an expected increase in the U.S. share from its current level of $44 \%$ to around $47 \%$ in 25 years.

If the adjustment were much slower than in this baseline simulation, so that $\alpha=0.98$ (rather than $\alpha=0.95$ ), then in order for the shares model to explain $\frac{C A_{t}}{Y_{t}^{V}}=-.07$, markets would have to be expecting a larger eventual increase in the U.S. share: $\frac{\bar{\gamma}}{\gamma_{t}}=1.141$. But because this implies slower adjustment, the implication is that the growth in the U.S. share over the next 25 years is only $5.6 \%$ (i.e., from $44 \%$ to $46.5 \%$.)

Alternatively, if the adjustment were much faster $-\alpha=0.75$ - then in order to explain a current account/net GDP ratio of -.07, the U.S. share would need to grow $7.6 \%$ in the long run. But essentially all of that share growth would occur over the next 25 years, meaning the U.S. share in Figure 2 would rise from $44 \%$ to $47.3 \%$.

None of these scenarios seems wildly implausible.

Equation (10) is based on an approximation that measures the current account as $C A_{t} \approx N X_{t}+\left(R_{t}-\Upsilon_{t}^{W}\right) B_{t}$, when really $C A_{t}=N X_{t}+\left(R_{t}-1\right) B_{t}$. The discrepancy between our measure and the true measure is $\left(\Upsilon_{t}^{W}-1\right) B_{t}$. According to the model, $\left|\left(\Upsilon_{t}-1\right) B_{t}\right|<\left|\left(R_{t}-1\right) B_{t}\right|$. We ignore the discrepancy because Figure 5 indicates that the net factor payments for the U.S. 
are nearly zero, but slightly positive. That is, although $B_{t}<0,\left(R_{t}-1\right) B_{t}$ is slightly positive for the U.S. We are not entirely sure what is the best way to treat $\left(\Upsilon_{t}^{W}-1\right) B_{t}$, which is left out of equation (10). We could treat it as a small positive number, less than the net factor payments of the U.S. Or we can do the calculation that is most unfavorable for the hypothesis that the current account deficit in 2004 can be explained by the shares model: From Gourinchas and Rey (2005), the debt/GDP ratio for the U.S. in 2004 was approximately 26\%. Given that net GDP/total GDP in the U.S. in 2004 was about $62 \%$, we have $B_{t} / Y_{t}^{v} \approx-0.42$. Then, taking a world growth rate of $2 \%$, we conclude $\left(\Upsilon_{t}^{W}-1\right) B_{t} \approx-0.0084$. That is, the current account/net GDP ratio we need to explain is not -0.07 , but rather -0.0784 . In that case, under the baseline parameters $(\beta=0.98$, $\alpha=0.95)$, the required value for $\frac{\bar{\gamma}}{\gamma_{t}}$ is 1.110 . In turn, that implies that the U.S. share would need to rise $8.0 \%$ over the next 25 years (from $44 \%$ to $47.5 \%$ ) for the current account deficit to be optimal under the shares model.

In the Appendix of Engel and Rogers (2006) we analyze versions of the model with constant intertemporal elasticity of substitution (different from one), and explore the consequences of different discount factors in the two countries. We derive an equally simple expression for the current account, albeit under more restrictive assumptions on the structure of the model.

In the next section we extend the model to derive implications for the real U.S. dollar exchange rate. We empirically assess the shares model of the current account in section 4. Readers interested in the empirical evidence can skip directly to that section.

\section{Real Exchange Rate Model}

Obstfeld and Rogoff (2000a, 2004, 2005) have argued that the correction of the U.S. current account will require a large real depreciation. It is interesting to examine what the evolution of the real exchange rate would be if the current account deficit was optimal, reflecting expectations of growth in the U.S.'s share of world adjusted GDP. As in Obstfeld and Rogoff, we need to make some specific assumptions about preferences in order to derive results. 


\section{3.a. Model with Non-Traded Goods and Home Bias}

In each country, we assume preferences are a Cobb-Douglas aggregate over a nontraded consumption good, and a traded consumption aggregate:

$$
C_{t}=C_{N t}^{\delta} C_{T t}^{1-\delta}, \quad C_{t}^{*}=\left(C_{N t}^{*}\right)^{\delta}\left(C_{T t}^{*}\right)^{1-\delta} .
$$

The exact price indexes are given by:

$$
P_{t}=P_{N t}^{\delta} P_{T t}^{1-\delta}\left(\delta^{-\delta}(1-\delta)^{\delta-1}\right), \quad \quad P_{t}^{*}=\left(P_{N t}^{*}\right)^{\delta}\left(P_{T t}^{*}\right)^{1-\delta}\left(\delta^{-\delta}(1-\delta)^{\delta-1}\right) .
$$

Preferences over traded goods consumption, in turn, are a function of the consumption good produced in each country:

$$
C_{T t}=\left[\theta^{\frac{1}{\varepsilon}} C_{H t}^{\frac{\varepsilon-1}{\varepsilon}}+(1-\theta)^{\frac{1}{\varepsilon}} C_{F t}^{\frac{\varepsilon-1}{\varepsilon}}\right]^{\frac{\varepsilon}{\varepsilon-1}}, \quad C_{T t}^{*}=\left[(1-\theta)^{\frac{1}{\varepsilon}}\left(C_{H t}^{*}\right)^{\frac{\varepsilon-1}{\varepsilon}}+\theta^{\frac{1}{\varepsilon}}\left(C_{F t}^{*}\right)^{\frac{\varepsilon-1}{\varepsilon}}\right]^{\frac{\varepsilon}{\varepsilon-1}} .
$$

We assume here that preferences are symmetric, but that there is bias toward the consumption of the good produced locally $(\theta>1 / 2)$. This matches the assumption in Obstfeld and Rogoff (2004, 2005), and Benigno and Thoenissen (2003).

Price indexes are given by:

$$
P_{T t}=\left[\theta P_{H t}^{1-\varepsilon}+(1-\theta) P_{F t}^{1-\varepsilon}\right]^{\frac{1}{1-\varepsilon}}, \quad P_{T t}^{*}=\left[(1-\theta) P_{H t}^{1-\varepsilon}+\theta P_{F t}^{1-\varepsilon}\right]^{\frac{1}{1-\varepsilon}} .
$$

We have the following demand system:

(21) $\quad P_{N t} C_{N t}=\delta P_{t} C_{t}$

$$
\begin{aligned}
& P_{H t} C_{H t}=(1-\delta) \theta\left(\frac{P_{H t}}{P_{T t}}\right)^{1-\varepsilon} P_{t} C_{t} \\
& P_{N t} C_{N t}=\delta P_{t} C_{t} \\
& P_{H t}^{*} C_{H t}^{*}=(1-\delta)(1-\theta)\left(\frac{P_{H t}}{P_{T t}^{*}}\right)^{1-\varepsilon} P_{t}^{*} C_{t}^{*} \\
& P_{N t}^{*} C_{N t}^{*}=\delta P_{t}^{*} C_{t}^{*} .
\end{aligned}
$$

Using Walras' Law, we do not need to write down the demand for the foreign-produced traded good.

We will assume net debt service at time $t$ is equal to zero. That is because, in applying this model to the U.S. to examine how its real exchange rate will evolve going forward from 2004, we will use the approximation that its current debt service is approximately zero in 2004. (In the calculations below, period $t$ is defined as the period in which net debt service is zero.) In 
that case, equation (8) gives us $\frac{P_{t} C_{t}}{Y_{t}^{W}}=\Gamma_{t}$. But then, combining equations (2) and (4), we see that $\frac{P_{t} C_{t}}{Y_{t}^{W}}=\frac{P_{t+j} C_{t+j}}{Y_{t+j}^{W}}$, for all $j \geq 0$. That allows us to conclude that $\frac{P_{t+j} C_{t+j}}{Y_{t+j}^{W}}=\Gamma_{t}$, for all $j \geq 0$.

We set the price of the foreign traded good equal to one in each period ( $P_{F, t+j}=1$.) Then we derive the equilibrium conditions:

$$
\begin{aligned}
& \text { (24) } \gamma_{H, t+j}=(1-\delta)\left\{\frac{\theta P_{H, t+j}^{1-\varepsilon}}{\theta P_{H, t+j}^{1-\varepsilon}+1-\theta} \Gamma_{t}+\frac{(1-\theta) P_{H, t+j}^{1-\varepsilon}}{(1-\theta) P_{H, t+j}^{1-\varepsilon}+\theta}\left(1-\Gamma_{t}\right)\right\} . \\
& \text { (25) } \gamma_{N, t+j}=\delta \Gamma_{t} . \\
& \text { (26) } \gamma_{N, t+j}^{*}=\delta\left(1-\Gamma_{t}\right) .
\end{aligned}
$$

Here we define $\gamma_{H, t+j}$ and $\gamma_{N, t+j}$ to be the value of the home country's output of traded goods, and nontraded goods respectively, as a share of the value of world output. It is helpful to notice from (25) that because of the assumptions of unitary intertemporal elasticity of substitution and unitary elasticity of substitution between nontraded and traded goods, the value of each country's nontraded output as a share of world output is constant over time. We can write $\gamma_{N}=\delta \Gamma_{t}$, and $\gamma_{H, t+j}=\gamma_{t+j}-\delta \Gamma_{t}$.

The question we answer here is, if the U.S. current account is explained by the shares model, then under the baseline calibration of section 2.c, what are the implications for the evolution of the U.S. real exchange rate? So, assume the U.S. net GDP shares evolve as in equations (12) and (13) above (repeated here for convenience):

$$
\begin{aligned}
& \gamma_{t+j}=\alpha^{j} \gamma_{t}+\left(1-\alpha^{j}\right) \bar{\gamma}, \\
& \Gamma_{t}=\frac{1-\beta}{1-\alpha \beta} \gamma_{t}+\frac{\beta(1-\alpha)}{1-\alpha \beta} \bar{\gamma} .
\end{aligned}
$$

We can now use these equations to solve for $P_{H, t+j}$. Define $p_{t+j}=P_{H, t+j}^{1-\varepsilon}$. Given assumptions about $\gamma_{t}$ and $\bar{\gamma}$, we can use (13) to derive $\Gamma_{t}$, and (11) and (25) to derive $\gamma_{H, t+j}$. Then write equation (24) is a quadratic equation in $p_{t+j}$, whose solution is:

$$
p_{t+j}=\frac{A \theta^{2}+B(2 \theta-1) \pm \sqrt{\theta^{4}+2 C \theta^{2}(2 \theta-1)+B^{2}(2 \theta-1)^{2}}}{D \theta(1-\theta)}
$$


The parameters $A, B, C$, and $D$ are defined by:

$$
A=1-\frac{2 \gamma_{H, t+j}}{1-\delta} ; \quad B=\frac{\gamma_{H, t+j}}{1-\delta}+\Gamma_{0}-1 ; C=\Gamma_{0}\left(1-\frac{2 \gamma_{H, t+j}}{1-\delta}\right)+\frac{\gamma_{H, t+j}}{1-\delta}-1 ; D=2\left(\frac{\gamma_{H, t+j}}{1-\delta}-1\right) .
$$

We can then derive $P_{H, t+j}$ by using $P_{H, t+j}=p_{t+j}^{\frac{1}{1-\varepsilon}}$.

To summarize this section so far, we find that we can infer the behavior of the terms of trade given assumptions about the evolution of the home country's share of world net GDP. The home country's terms of trade - the price of its exports relative to its imports - is given by $P_{H, t+j}$, since the price of foreign traded goods is the numeraire. The reason that we can infer the terms of trade only from knowing the path of shares of GDP can be seen from equation (24). The right-hand-side of the equation shows that total world demand for the home traded good as a fraction of total world output depends only on $\Gamma_{t}$ and $P_{H, t+j}$. Demand depends only on these variables because total home consumption spending at time $t+j$ as a fraction of the value of world output at time $t+j$, is constant over time and determined by $\Gamma_{t}$. The preference structure gives us that demand for the home traded good in each country depends only on $P_{H, t+j}$ and total consumption spending in each country. The left-hand-side of equation (24) is the value of output of the home traded goods as a function of the value of total world output. But we have already seen that the assumption of log preferences over total expenditures, and Cobb-Douglas utility over consumption of non-traded goods and the traded goods aggregate gives us $\gamma_{H, t+j}=\gamma_{t+j}-\delta \Gamma_{t}$. So, once we make assumptions about the evolution of $\gamma_{t+j}$, we can derive $\Gamma_{t}$ and $\gamma_{H, t+j}$ and then use equation (24) to solve for $P_{H, t+j}$.

Ultimately, we are interested in calculating $\frac{Q_{t+j}}{Q_{t}}$, where $Q_{t} \equiv \frac{P_{t}^{*}}{P_{t}}$ is the C.P.I. real exchange rate (defined so that a home real depreciation is an increase in $Q_{t}$ ), over some time horizon from $t$ to $t+j$. Using the definitions of the price indexes in (17), we have

$$
Q_{t}=\left(\frac{P_{N t}^{*}}{P_{N t}}\right)^{\delta}\left(\frac{P_{T t}^{*}}{P_{T t}}\right)^{1-\delta}
$$

Since we are setting $P_{F t}=1$, our solution for $P_{H t}$ allows us to solve for $P_{T t}^{*}$ and $P_{T t}$. But we still need to solve for the paths of prices of non-traded goods in each country. 
We consider a model in which output is produced using labor, and labor is mobile between the traded and non-traded sector in each country. Output of the traded sector in the home country is given by $Y_{H t}=A_{H t} L_{H t}$, and in the nontraded sector by $Y_{N t}=A_{N t}\left(L-L_{H t}\right)$. (We are now considering a model with no population growth.) Here, $A_{H t}$ and $A_{N t}$ represent productivity, which may grow over time. These equations incorporate labor market equilibrium, with the assumption that the labor supply is fixed and equal to $L$. If labor markets are competitive, then we have $\frac{P_{N t}}{P_{H t}}=\frac{A_{H t}}{A_{N t}}$, or $P_{N t}=\frac{A_{H t}}{A_{N t}} P_{H t}$. Similarly in the foreign country, we get $\frac{P_{N t}^{*}}{P_{F t}^{*}}=P_{N t}^{*}=\frac{A_{F t}^{*}}{A_{N t}^{*}}$

We then have

$$
Q_{t}=\left(\frac{\left(A_{F t}^{*} / A_{N t}^{*}\right)}{\left(A_{H t} / A_{N t}\right)}\right)^{\delta}\left(\frac{1}{P_{H t}}\right)^{\delta}\left(\frac{P_{T t}^{*}}{P_{T t}}\right)^{1-\delta} .
$$

On the one hand, we have argued that if the home country's output of the traded good is growing more quickly than the foreign country's, then $P_{H t}$ must be falling. That implies that the $\left(\frac{1}{P_{H t}}\right)^{\delta}$ term in equation (29) must be rising. In addition, if there is home bias in consumption of traded goods, the $\left(\frac{P_{T t}^{*}}{P_{T t}}\right)^{1-\delta}$ term is also rising. Both contribute to a real depreciation for the home country. But working in the other direction is the fact that the relative growth in the home country's traded output is coming from productivity growth in the traded sector. Unless home's relative growth advantage in the nontraded sector is greater than its relative growth advantage in the traded sector, $\left(\frac{\left(A_{F t}^{*} / A_{N t}^{*}\right)}{\left(A_{H t} / A_{N t}\right)}\right)^{\delta}$ will be falling. This is the standard Balassa-Samuelson effect. This latter effect might well outweigh the first two effects, so on net home could be experiencing a real appreciation along the adjustment path as its current account deficit declines.

To review, rather than beginning from assumptions on the growth of productivity in each of four sectors (traded and non-traded in each country), we have taken a slightly different tack to inferring real exchange rate behavior. We have found that if we make assumptions about the 
evolution of GDP shares and relative productivity within each country $\left(A_{H t} / A_{N t}\right.$ and $A_{F t}^{*} / A_{N t}^{*}$ ), we can infer the path of the real exchange rate. In essence, we make an assumption on the path of an endogenous variable $\left(\gamma_{t}\right)$ instead of an exogenous variable $\left(A_{H, t} / A_{F, t}^{*}\right)$ to solve for the real exchange rate.

\section{3.b Model Simulations for the U.S. Real Exchange Rate}

Now suppose we take as input the assumption that the long-term growth in the U.S. share

is given by $\frac{\bar{\gamma}}{\gamma_{t}}=1.098$, so that the 25-year growth in the U.S. share is $7.1 \%$, and $\frac{C A_{t}}{Y_{t}^{V}}=-.07$ is optimal. What will the evolution of prices look like in such a model?

In addition to assuming $\beta=0.98$ and $\alpha=0.95$, we need to make assumptions on the degree of home bias in consumption of traded goods, the share of nontraded goods in consumption, and the elasticity of substitution between home and foreign goods. We choose these to be $\theta=0.7, \delta=0.75$, and $\varepsilon=6$, respectively, to match the assumptions of Obstfeld and Rogoff (2000a, 200b, 2004), though we discuss the choice of $\varepsilon$ in greater detail below.

From equation (27), we can determine the terms of trade. These assumptions imply a terms of trade deterioration of $6.8 \%$ over the next 25 years.

We must make an assumption about the change in $\frac{A_{F t}^{*} / A_{N t}^{*}}{A_{H t} / A_{N t}}$ : the productivity of the rest of the world's traded sector relative to its nontraded sector, compared in turn to the same relative productivity in the U.S. If we assume that the relative productivity growth in the home traded/non-traded sector is equal to that in the foreign country, we find that the U.S. will experience a cumulative real depreciation of only 6.1\% over the next 25 years. If the U.S. current account deficit reflects expectations of an increase in the U.S. future share of world GDP, and if the reduction of the U.S. current account occurs as part of an optimal adjustment path, then the required change in the U.S. real exchange rate might be quite small, contrary to Obstfeld and Rogoff (2004).

In fact, if the growth in productivity in traded vs. non-traded goods is only slightly faster in the U.S. than in the rest of the world (8.3\% cumulated over 25 years), there will be no change in the real exchange rate. In this case, because of the Balassa-Samuelson effect, U.S. non-traded 
goods prices will increase just enough to offset the effect of deteriorating terms of trade in tandem with home bias in consumption of traded goods.

Suppose under these same assumptions that the elasticity of substitution between home and foreign goods were lower - equal to two. Then the effects on the real exchange rate would be more dramatic. The terms of trade for the U.S. would deteriorate by $29.7 \%$ and the U.S. would experience a 26.9\% real depreciation over the next 25 years. On the other hand, we have followed Obstfeld and Rogoff (2004) in assuming that the home bias parameter is $\theta=0.7$ and non-traded good's share in home consumption is $\delta=0.75$. Still assuming $\varepsilon=2$, reducing these to $\theta=0.55$ and $\delta=0.70$ reduces the implied real depreciation to $13.3 \%$ over the next 25 years.

Obstfeld and Rogoff (2000b) choose $\varepsilon=6$ for their simulations. They survey several micro-based studies of the elasticity of substitution in international trade, and conclude that most estimates are in the range of $\varepsilon=6$ or higher. But, there are two concerns that lead Obstfeld and Rogoff (2004) to choose $\varepsilon=2$ in their later study: "both because short-run trade elasticities are smaller and because estimates based on micro data are quite a bit larger than those estimated to apply to aggregated U.S. trade flows.”

We view adjustment of the current account to be a longer-run event, so perhaps long-run elasticities are more relevant. But another concern is whether the change in prices we are considering is permanent or temporary. Ruhl (2005) argues that the difference in macro and micro estimates of the elasticities hinges on the persistence of the shock to the terms of trade. Macro estimates have focused on changes at business cycle frequencies, but micro studies have looked at permanent price changes. Ruhl estimates (using "macro" data from NAFTA countries, and their response to tariff changes) that the elasticity of demand in response to permanent changes is 6.2, while for temporary changes it is 1.4. Since we are investigating the behavior of a model in which there is a permanent change in the shares of net GDP, leading to a permanent change in the terms of trade, the higher elasticity is more appropriate for our calibration by this criterion.

Obstfeld and Rogoff (2000a. 2004, 2005) consider models in which factors are immobile between sectors. They model output simply as an endowment that changes over time, though this could be thought of as a change in productivity with fixed factor inputs. As we have noted, $P_{H t}$ is determined by our assumption about the path of GDP shares, but in order to determine the 
path of the real exchange rate, we must establish the path of adjustment for non-traded goods prices. An implication of (25) and (26) is:

$$
\frac{P_{N, t+j} Y_{N, t+j}}{P_{N, t} Y_{N, t}}=\frac{P_{N, t+j}^{*} Y_{N, t+j}^{*}}{P_{N, t}^{*} Y_{N, t}^{*}} .
$$

We can rewrite this as

$$
\left(\frac{P_{N, t+j}^{*}}{P_{N, t}^{*}}\right) /\left(\frac{P_{N, t+j}}{P_{N, t}}\right)=\left(\frac{Y_{N, t+j}}{Y_{N, t}}\right) /\left(\frac{Y_{N, t+j}^{*}}{Y_{N, t}^{*}}\right) .
$$

In the endowment model, then, we only need to make an assumption about the relative growth of the non-traded sector in the home relative to the foreign country to derive the change in the relative price of non-traded goods.

In this case, when $\theta=0.7, \delta=0.75$, and $\varepsilon=6$ (and $\beta=0.98, \alpha=0.95$ ), and if we assume equal growth in the endowment of the non-traded industries in home and foreign, we find there is essentially no change in the real exchange rate over 25 years. There is a cumulative real depreciation of $0.6 \%$. If however we assume endowment growth is substantially higher in the home country - a cumulative $15 \%$ increase - then there is a real depreciation of $11.8 \%$. When we reduce the elasticity of substitution between home and foreign traded goods to 2, then with equal growth in the endowment of non-traded goods, there is a cumulative real depreciation of $3.4 \%$. When the home output of non-traded goods rises by $15 \%$ relative to the foreign endowment, and $\varepsilon=2$, then home experiences a $14.8 \%$ real depreciation. So, in the endowment model, the real exchange rate movements are not so sensitive to different assumptions on the magnitude of $\varepsilon$, but do depend crucially on the projected productivity growth of non-tradeables.

\section{Empirical Evidence on the Current Account Model}

\section{4.a. A Direct Test of Current Account Sustainability}

We begin by conducting standard empirical tests of intertemporal sustainability conditions for the U.S. current account along the lines Bohn (1998, 2004, 2005) has pursued for the U.S. government budget. As described in the Appendix of Engel and Rogers (2006), the essential prediction we test is that as a country accumulates debt, its net exports will rise. We use annual data from 1790-2004 on merchandise exports $(X)$ and imports $(M)$, gross national product (GNP), and (minus) the Net Financial Position of the U.S. (ExtDebt). As shown in Table 1, and foreshadowed above (Fig. 3), the essential prediction of the model is violated in the data, 
clearly in the latter part of the sample. The results appear to confirm the conventional view that the U.S. external balances are on an unsustainable trajectory.

\section{4.b. Markov-Switching Model for Net GDP Shares}

Next we directly estimate the model of the current account derived in section 2 . We repeat equation (11) for convenience:

$$
z_{t} \gamma_{t}=\beta \gamma_{t}-(1-\beta) E_{t}\left[\beta \gamma_{t+1}+\beta^{2} \gamma_{t+2}+\ldots\right]
$$

Recall $z_{t} \equiv C A_{t} / Y_{t}^{V}$. We estimate a time-series model for the shares, $\gamma_{t+j}$, and compare the implied value for $z_{t} \gamma_{t}$ from the right-hand-side of equation (11) to the actual value.

The problem with estimating a model for the shares is that they appear to be following an upward linear trend (Figure 2). We need to make an assumption about how this trend is going to end. We explore a model that is consistent with the view that the U.S. share will continue to grow, though eventually the share is expected to converge to a level higher than its current level.

We implement this by assuming that the evolution of shares in Figure 2 is described by a switching model. It appears that the shares follow a persistent process from 1975 to the mid1980s, with a mean of approximately 0.385. Some time in the mid-1980s, the U.S. share of advanced country GDP begins to grow. We model this as a switch toward a new regime, in which the shares are expected to converge to a level higher than 0.385. The data, however, cannot be allowed to choose the mean of this second state, because there has been no apparent convergence to any value below the value for the last data point in 2004:IV. So we pick a mean for the second state (but try out different values to see how sensitive the model is to the choice.)

Assume that the shares follow a Markov switching process, where the process switches between two stationary $\mathrm{AR}(1)$ processes. In state 1 , the shares follow:

$$
\gamma_{t+1}=\alpha_{1}+\rho \gamma_{t}+u_{1, t+1} .
$$

In state 2, the shares follow the process:

$$
\gamma_{t+1}=\alpha_{2}+\rho \gamma_{t}+u_{2, t+1}, \quad \alpha_{2}>\alpha_{1} .
$$

We assume that the autoregressive coefficient is the same in both states, and that $u_{1 t}$ and $u_{2 t}$ : are both normally distributed, mean 0 , and variance $\sigma^{2}$. In estimation, we impose a value for the mean in state 2, which is given by $\bar{\gamma}_{2}=\frac{\alpha_{2}}{1-\rho}$. 
Define $p \equiv \operatorname{Pr}\left(s_{t+1}=1 \mid s_{t}=1\right)$ and $q \equiv \operatorname{Pr}\left(s_{t+1}=2 \mid s_{t}=2\right)$.

Let $\pi_{t}$ be the "filter probability" that the state at time t is state 1 . The filter probability can be thought of as follows: Suppose we knew the parameters of the stochastic process ( $\rho, \alpha_{1}$, $\alpha_{2}, p, q$, and $\sigma^{2}$ ), and we observed the data up to and including time t. Then $\pi_{t}$ is the Bayesian probability that the state at time $t$ is state 1 . More precisely, call $\Omega_{t}$ the information set that includes observable data up to and including time $t$. It does not include knowledge of the state at time $t$ or any other time. Then $\pi_{t} \equiv \operatorname{prob}\left(s_{t}=1 \mid \Omega_{t}\right) . \bar{\pi}$ is a function of the parameters, given by: $\bar{\pi}=\frac{1-q}{2-p-q}$. In model estimation, we assume $\pi_{0}=1$. That is, initially we are certain we are in state 1.

At each period $t$, we calculate the probability of state 1 or state 2 for every period from $t$ onward: $\theta_{t j}=\operatorname{prob}\left[s_{t+j}=1 \mid \Omega_{t}\right]$. (So, $\pi_{t}=\theta_{t 0}$.) With a little bit of work, we have:

$$
\theta_{t j}=\bar{\pi}+(p+q-1)^{j}\left(\pi_{t}-\bar{\pi}\right)
$$

where $\bar{\pi}$ is the unconditional probability of state 1 , given by $\bar{\pi}=\frac{1-q}{2-p-q}$.

With equation (31), we can now calculate $E_{t} \gamma_{t+j} \equiv E\left[\gamma_{t+j} \mid \Omega_{t}\right]$. We can iterate:

$$
E_{t} \gamma_{t+j}=\left[\theta_{t j}+\rho \theta_{t j-1}+\ldots+\rho^{j-1} \theta_{t 1}\right] \alpha_{1}+\left[1-\theta_{t j}+\rho\left(1-\theta_{t j-1}\right)+\ldots+\rho^{j-1}\left(1-\theta_{t 1}\right)\right] \alpha_{2}+\rho^{j} \gamma_{t}
$$

Then substitute the expression for $\theta_{t j}$ from equation (31), and we get:

(32) $E_{t} \gamma_{t+j}=\left(\bar{\pi} \alpha_{1}+(1-\bar{\pi}) \alpha_{2}\right)\left(\frac{1-\rho^{j}}{1-\rho}\right)+\rho^{j} \gamma_{t}+\frac{\left(\alpha_{1}-\alpha_{2}\right)\left(\pi_{t}-\bar{\pi}\right)(p+q-1)\left[(p+q-1)^{j}-\rho^{j}\right]}{p+q-1-\rho}$

Up to now, this was all a discussion of the statistical model of the shares, $\gamma_{t}$. Now we want to relate it to the model of the current account. Substitute in from equation (32) and we can calculate the infinite sum on the right-hand-side of (11) as:

(33) $E_{t}\left[\beta \gamma_{t+1}+\beta^{2} \gamma_{t+2}+\ldots\right]=\frac{\beta\left(\bar{\pi} \alpha_{1}+(1-\bar{\pi}) \alpha_{2}\right)}{(1-\beta)(1-\beta \rho)}+\frac{\beta \rho}{1-\beta \rho} \gamma_{t}+\frac{\beta\left(\alpha_{1}-\alpha_{2}\right)\left(\pi_{t}-\bar{\pi}\right)(p+q-1)}{(1-\beta(p+q-1))(1-\beta \rho)}$

Then we can write equation (11), with some rearrangement, as: 


$$
\begin{aligned}
z_{t} \gamma_{t}= & \frac{\beta}{1-\beta \rho}\left[\frac{\left(\alpha_{1}-\alpha_{2}\right) \bar{\pi}(p+q-1)(1-\beta)}{1-\beta(p+q-1)}-\left(\bar{\pi} \alpha_{1}+(1-\bar{\pi}) \alpha_{2}\right)\right] \\
& +\frac{\beta(1-\rho)}{1-\beta \rho} \gamma_{t}+\frac{\left(\alpha_{2}-\alpha_{1}\right)(p+q-1) \beta(1-\beta)}{(1-\beta(p+q-1))(1-\beta \rho)} \pi_{t}
\end{aligned}
$$

This expression is linear in $\gamma_{t}$ and $\pi_{t}$. In the data, $z_{t} \gamma_{t}$ is falling over time, because our current account is becoming more negative. But $\gamma_{t}$ is rising, and the coefficient on $\gamma_{t}$ in equation (34) is positive. That works against our model's ability to explain the current account. The intuition is that if we only had one state of the world, and shares followed an autoregressive process, then equation (6) would simplify to an expression in which $z_{t} \gamma_{t}$ was positively related to $\gamma_{t}-\bar{\gamma}$. If $\gamma_{t}-\bar{\gamma}$ were positive, then we would anticipate that home's share of world income would be falling, so its current account should be positive. The larger is $\gamma_{t}-\bar{\gamma}$, the larger $z_{t} \gamma_{t}$, which explains the positive coefficient on $\gamma_{t}$ in equation (34).

How could this model possibly fit the data? The filter probability of being in state $1, \pi_{t}$, is falling over the sample. As long as $p+q>1$, the coefficient on $\pi_{t}$ is positive. That will give us a force leading to a decline in $z_{t} \gamma_{t}$. This force will be bigger the larger is $\alpha_{2}=(1-\rho) \bar{\gamma}_{2}$. That is true for two reasons. First, the coefficient on $\pi_{t}$ in equation (34) is larger when $\alpha_{2}$ is larger. Second, when $\alpha_{2}$ is larger, $\pi_{t}$ will be rising throughout the sample. Put another way, if $\alpha_{2}$ were relatively small (not much bigger than $\alpha_{1}$ ), then we would pretty quickly infer that we were in state 2 . In this case $\pi_{t}$ would be close to zero, so it would not be able to fall much further.

It turns out that this model is unsuccessful in fitting the U.S. current account. We estimated the model imposing various assumptions about the mean share in state $2, \bar{\gamma}_{2}=\frac{\alpha_{2}}{1-\rho}$. The dimension along which the model failed is similar for the entire range of values of $\bar{\gamma}_{2}$ that we tried. Even though for some choices of $\bar{\gamma}_{2}$ our model can explain the large U.S. current account deficits in 2004, the model predicts that deficits should have been even larger prior to 2004. That is, given the behavior of net GDP shares depicted in Figure 2, the market should have quickly learned that the regime had switched from the low-mean to the high-mean state. As 
soon as it learns that we are in the high mean state, the value of $E_{t}\left[\beta \gamma_{t+1}+\beta^{2} \gamma_{t+2}+\ldots\right]$ grows large relative to the current value of $\gamma_{t}$, and the current account falls into deficit. Over time, as the model predicts, the current account deficit falls.

Figure 6 plots the actual values of $z_{t} \gamma_{t}$ along with the fitted values of the right-hand-side of equation (11) for the case in which we impose $\bar{\gamma}_{2}=0.49$. In this case, the model matches well the actual value of $z_{t} \gamma_{t}$ in 2004, approximately 0.03 (a current account /net GDP ratio of -.07, times a share of world GDP share around .435.) But the model predicts that the value of $z_{t} \gamma_{t}$ should have been much lower (much higher in absolute value) than it was for most of the earlier sample..

The estimated parameters of the model are $p=0.979, q=1.000, \rho=0.992, \bar{\gamma}_{1}=0.416$. Given that we have imposed a high mean for state 2, and given the behavior of shares in Figure 2 , it is not surprising that we estimate $q=1.000$. Note that the estimate of $\bar{\gamma}_{1}=0.416$ is actually quite high relative to the realizations of net GDP shares in the early part of our sample. As a result, the future GDP share is expected to increase even when the filter probability of being in state 1 is high in the early part of the sample.

In calculating the fitted values of equation (11), we use $\beta=.995$, which for quarterly data is approximately equivalent to our assumption that $\beta=.98$ for annual discounting in our simulations. Substituting the parameter estimates into equation (34), we find that the coefficient on $\gamma_{t}$ is 0.581 , while that on $\pi_{t}$ is only 0.008. $\gamma_{t}$ rises from around 0.38 to 0.435 from 1985 to 2004. The effect of that increase, from equation (34), is to raise $z_{t} \gamma_{t}$ by .032 from the mid-1980s to 2004. That effect must outweigh the influence of gradual learning that the state has shifted from state 1 to state 2 . That effect can contribute to a decrease in $z_{t} \gamma_{t}$ of 0.008 at most.

It is easy to understand the failure of the model by reconsidering equation (10):

$$
\frac{C A_{t}}{Y_{t}^{V}}=1-\frac{\Gamma_{t}}{\gamma_{t}} .
$$

In order to produce an increasing current account deficit, we need a model that not only produces an increasing value for $\Gamma_{t}$ for the US (and the model does produce this), but we must have $\Gamma_{t}$ increasing faster than $\gamma_{t}$. It is this latter feature that the Markov-switching model fails to 
produce. While the model can explain a rising discounted sum of expected share of future world GDP, the actual US share rose even faster in the 1990s.

One possible explanation for our empirical findings is that markets were consistently surprised about the size of U.S. GDP growth. Our Markov-switching model incorporates learning about the true state, but it assumes that agents know the parameters of state 2 . That is, agents know that the U.S. might switch to a regime where its GDP share grows as large as 0.49. Perhaps agents were not even aware of this possibility, and only gradually learned about how sustained U.S. growth would be relative to the rest of the advanced world. We turn to some evidence on market expectations.

\section{4.c. Consensus Forecasts}

We provide estimates of future GDP shares based on survey data from Consensus Forecasts, a publication of Consensus Economics Ltd. (www.consensuseconomics.com). Every month, they survey over 240 prominent financial and economic forecasters for their estimates of a range of variables including future growth, inflation, interest rates and exchange rates. More than 20 countries are covered. Twice a year, long-range forecasts (10 years or longer) are provided, making this an ideal source for us.

The December 1993 issue of Consensus Forecasts contains expected future real GDP growth rates for each of the G-7 in each year from 1994-2004. Using this and the formula described above for calculating GDP shares, we compute the path of the U.S. share of G-7 GDP that agents implicitly forecasted in December 1993. The expected U.S. share is given in the first row of Table 2. Agents were forecasting a relatively flat path of the U.S. share of output, from 40.9\% in 1994 to $41.1 \%$ in 2004. As it turned out, however, GDP rose much faster in the U.S. than the rest of the G-7, and the U.S. share rose from 40.4\% in 1993 to $44.7 \%$ in 2004 (as reported in the second row of Table 2.) Of course, this rise in the U.S. output share coincided with the productivity boom in the United States. These gains were almost completely unexpected.

The next table provides evidence on the evolution of these forecasted paths during the 1990s. The first column repeats the final column of the previous table, showing that the $1.6 \%$ forecasted rise in the U.S. share was much smaller than the actual 10.6\% rise from 1993 to 2004. Using various issues of Consensus Forecasts in subsequent years, we repeat this calculation over different sub-periods in the following columns. As of 1994, for example, survey respondents 
forecasted a slight decline in the U.S. share through 2004, well below the actual $8.4 \%$ rise in the share (column 2 of Table 3). Indeed, throughout the 1990s agents repeatedly underpredicted the rise in the U.S. output share.

From the perspective of our shares model and the puzzle as to why the U.S. current account deficit did not appear even earlier, this survey evidence suggests a partial explanation. It seems that it took some time - - nearly a decade in fact - - for agents to learn about the rise in the U.S. share of output, a rise that was already well under way.

Finally, Table 4 presents evidence about agents' expectations through 2017, based on the August 2005 issue of Consensus Forecasts. The relatively optimistic forecasts for U.S. growth (3 percent or greater for each year) compared to the foreign G-7 (e.g., around 1.5 percent for Japan and Germany) translates into an expected path of the U.S. share that rises from around 45\% in 2005 to nearly 49\% by 2017. Recalling our earlier calibrations, these numbers suggest that the present level of the U.S. current account deficit cannot easily be dismissed as inconsistent with optimal consumption decisions.

Figure 7 is a graphical presentation of some of this evidence. It plots the forecast in 1993 for the U.S. share of G7 GDP, 1993-2004, and the forecast in 2005 for the U.S. share of G-7 GDP, 2005-2017. It also plots the actual U.S. share of G-7 GDP, 1993-2004. This chart emphasizes two points: First, actual U.S. GDP shares grew much faster than was forecast in the 1993-2004 period. Second, the forecast today for future GDP shares is much more optimistic than it was in 1993.

A natural question is whether our current account model, given by (11), could explain actual current account from 1994-2004 if we used the Consensus Forecasts in each year to construct expectations of future shares. For each year, we construct forecasts of the U.S. share of G7 GDP for the following 12 years. ${ }^{10}$ We can then construct the expected present discounted value of shares, $\Gamma_{t} \equiv(1-\beta) E_{t}\left[\gamma_{t}+\beta \gamma_{t+1}+\beta^{2} \gamma_{t+2}+\ldots\right]$. This is an infinite sum, so we need to make an assumption about the forecast for shares beyond the horizon of Consensus Forecasts. We assume that the forecast is for the U.S. share to remain constant at the level it is forecast to be 12 years out.

\footnotetext{
${ }^{10}$ Our model calls for forecasts of shares of net GDP, but there is very little difference between shares of total GDP and net GDP.
} 
We then use (10) to construct the model's implied current account/net GDP ratio:

$$
\frac{C A_{t}}{Y_{t}^{V}}=1-\frac{\Gamma_{t}}{\gamma_{t}}
$$

Figure 8 plots the actual values of $C A_{t} / Y_{t}^{v}$ and those implied by the model. The model fits the data remarkably well, particularly in 1998-2004, especially considering that the model uses only one variable $\left(\Gamma_{t} / \gamma_{t}\right)$ and no estimated parameters (we set $\left.\beta=0.98\right)$. The key feature is that while both $\Gamma_{t}$ and $\gamma_{t}$ are rising over this time period, our measure of $\Gamma_{t}$ rises faster than $\gamma_{t}$

Regressing the actual data $z_{t} \equiv \frac{C A_{t}}{Y_{t}^{V}}$ on the model's prediction, $z_{t}^{P}$, we find:

$$
z_{t}=-0.020+0.642 z_{t}^{p} \quad R^{2}=0.951
$$

(0.003) (0.049)

Apparently one reasonable explanation for the declining current account in the U.S. has been the rising expectations of GDP growth in the U.S. relative to other advanced countries. The measure of expectations constructed in the Markov-switching model implies that agents knew even in the 1980s that the U.S. share of advanced country GDP would rise dramatically in the 1990s. This is inconsistent with the survey data. But the fact that survey forecasters missed the U.S. growth relative to the rest of the G-7 for several years in a row does not imply their forecasts were irrational. It is simply not possible to assess whether expectations of long-run growth have systematic biases in a relatively short sample. Currently, the Consensus Forecast is for strong relative U.S. growth for the next dozen years. It is hard to argue that the consensus view is wildly implausible. If these forecasts are regarded as reasonable measures of expectations, the simple "shares" model predicts recent U.S. current account deficits fairly precisely.

\section{Conclusions}

We have asked whether the U.S. current account deficit could be consistent with expectations that the U.S. share of world GDP will increase. Under assumptions about the growth in the net GDP share that are not wildly implausible, the level of the deficit can be consistent with optimal saving behavior. But, in making this assessment, we emphasize that 
there are many difficult issues to deal with, and the conclusion is sensitive to how one handles these questions.

First, our findings are sensitive to how we treat two problems: the high saving rate in East Asian emerging economies, and the "exorbitant privilege" (the term used by Gourinchas and Rey (2005)) that allows the U.S. to receive a much higher return on its foreign investments than foreigners earn on their U.S. investments.

On the first point, most forecasters predict that the emerging market's share of world GDP will be increasing over time. Our empirical work does not include these countries, and if it did, the forecast path of the U.S. share of world GDP would not be as rosy. But, according to the model, these countries ought to be borrowers in international capital markets. They are not -they are large net lenders. It is puzzling that they are net lenders. Bernanke (2004) refers to this as a "savings glut", and hypothesizes that these countries are in essence building up a nest egg in order to protect them against a possible future international financial crisis such as the one that beset East Asia in 1997-1998.

We are not sure how to handle this in our model. These countries may continue to be high savers, in which case they will hold down world interest rates and the U.S. deficits will be more justifiable. On the other hand, their saving rate may fall and real interest rates may rise, which works toward the U.S. optimally having a smaller deficit.

We make the "heroic" assumption that these countries are not contributing to net world saving at all. On the one hand, this is a conservative assumption (if one is trying to explain the large U.S. deficits), because the countries are in fact large net savers. On the other hand, if their net saving is reversed, the assumption is too optimistic.

It does seem like markets favor the position that these countries will maintain their positions as large savers, because long term real interest rates are low. However, much of the recent scholarly and policy-oriented research on the U.S. current account deficit has taken the position that the markets may not be correctly foreseeing events.

Finally, it is possible that the saving rate is high in East Asian countries because of demographic factors. It has been noted that because of the one-child policy, the ratio of old to young is increasing rapidly in China. There are other countries for which demographic factors may be very important as well, and this deserves further study. 
We take a similar neutral position on the exorbitant privilege. One possibility is that the U.S. will continue to receive higher returns on its foreign investments than it pays out on its foreign borrowing. On the other hand, that privilege may disappear, and worse, it may disappear not only for future borrowing but also for our outstanding debt when it is refinanced. Our work takes a somewhat neutral position by assuming future borrowing and lending takes place at the same rate of return, but that there is no additional burden to be encountered from refinancing existing debt at less favorable rates of return.

There really are a variety of scenarios that could play out. As Gourinchas and Rey (2005) demonstrate, it is not only that the return on U.S. assets within each asset class is lower than on foreign assets (implying the market views U.S. assets as less risky), but also that the mix of U.S. investments abroad favors riskier classes of assets. It is possible that the U.S. net return will fall in the future both because the risk premium on U.S. assets rises (as in Edwards (2005) or Blanchard, Giavazzi and Sa (2004)), and because foreigners shift toward investing in more risky U.S. assets. But, again, it is notable that markets do not reflect any increasing riskiness of U.S. assets.

With these major caveats in mind, we find that the size of the U.S. current account deficit may be justifiable if markets expect further growth in the U.S. share of advanced-country GDP. The growth that is needed does not appear to be implausible.

But, what the model cannot explain is why the U.S. current account deficit continues to grow. If households expect the U.S. share of world GDP to grow, they should frontload consumption. The deficits should appear immediately, not gradually.

We have allowed in our Markov-switching model for the possibility that there was a shift in regime that U.S. households only gradually learned about. But that was not able to explain the rising U.S. current account deficits. However, our simulations and estimation assumed that households understood that if a regime shift took place, the U.S. share of world GDP in the long term would be much higher than it was in the early 1980s. In practice, markets may have only gradually learned the U.S. long-term share. Incorporating gradual learning about the parameters of the model will be left for future work. It is possible that because U.S. households only gradually came to the realization that their share of advanced country GDP was going to be much higher in the long run, they only gradually increased their borrowing on world markets. 
This possibility is supported by our examination of the consensus long-term forecasts of U.S. GDP relative to G-7 GDP since 1993. These forecasts have consistently underestimated U.S. GDP growth relative to other countries, by wide margins. The current forecasts for the future, however, show that the markets expect a large increase in the U.S. share of GDP - almost precisely the amount that we calculate would make the current level of the deficit optimal.

There are at least two other possible explanations to explain this gradual emergence of the current account deficit. One possibility is that it takes time for consumption to adjust. This could be modeled either with adjustment costs, or, as is popular in many calibrated macro models, with habit persistence in consumption.

Another possibility is that there has been a steady relaxation of credit constraints for many U.S. households, as well as increased access to U.S. capital markets for foreign lenders. The relaxation of credit constraints was one of the possibilities that Parker (1999) explored in his study of the decline in U.S. saving. He found that it could explain at most $30 \%$ of the increase in consumption from 1959 to 1998. The starting point of Parker's back-of-the-envelope calculation is the observation that the consumption boom is the equivalent of three-quarters of one year's GDP in present value terms. The rise in debt, as measured by the difference in ratios of household total assets to income and net worth to income, was about 20 percent over the period. Therefore, debt can explain at most .20/.75 < 30 percent of the increase in consumption. Since the time Parker wrote his paper, debt has continued to rise, by another 25\% through 2005 Q2 when the ratio of total assets to income exceeded the ratio of net worth to income by 1.24.

Of course, the other obvious candidate for the increasing U.S. current account deficit is through the effect of U.S government budget deficits. Since government spending as a share of GDP has not changed dramatically, we are really talking about the effects of tax cuts. ${ }^{11}$ But our model assumes that the timing of taxes does not matter for household consumption -- that Ricardian equivalence holds. Obviously that might not be correct. Recent empirical studies do not show much support for Ricardian equivalence, though the point is debated (Gale-Orszag, 2004, and Engen-Hubbard, 2004). We note that to the extent that credit constraints have been relaxed in recent years, Ricardian equivalence becomes a more credible possibility. It may be

\footnotetext{
${ }^{11}$ Our analysis allows for the effects of increases in government spending. An increase in current spending above the long-run spending levels would lower the U.S. share of GDP net of government spending and investment relative to future shares, thus inducing a greater consumption to net GDP ratio.
} 
that in more recent years, lower taxes do not boost consumption as much, and instead allow households to pay off some of their credit card debt or prepay some of their mortgage. It may be interesting to pursue empirically the hypothesis that the effects on national saving of tax cuts varies with the degree of credit constraints in the economy.

Another argument that needs to be explored is the distributional effects of the recent tax cuts. It has been argued that the tax cuts were less stimulative than previous cuts because they accrued mostly to wealthy individuals, who simply saved the additional after-tax income. (That is, the rich act more like Ricardian consumers.) But if that is the case, then it is more difficult to make the case that the tax cuts are responsible for the decline in U.S. national saving.

Finally, we cannot reach firm conclusions about the future path of U.S. real exchange rates. We have calibrated a model that is essentially identical to Obstfeld and Rogoff (2004), but one in which the consumption path is determined endogenously as a function of current and expected discounted real income. We found that under one set of baseline assumptions, there should not be much change in the equilibrium real exchange rate as the U.S. current account adjusts. Our model assumes the U.S. will experience higher growth in productivity in both traded and non-traded sectors, and that there is factor mobility between the traded and non-traded sector. On the one hand, if traded/non-traded productivity growth in the U.S. is slightly higher than in the rest of the world, the price of non-traded goods will rise in the U.S. from the BalassaSamuelson effect. On the other hand, the U.S. terms of trade should fall as the supply of its exports increases. If there is home bias in consumption of tradables, that would work toward causing a U.S. real depreciation. In our baseline calibration, these two effects approximately cancel.

But as we have noted, the conclusions about the real exchange rate depend on assumptions about parameters of the model. Particularly, if the elasticity of substitution between imports and exports in consumption is much lower than our baseline simulation assumed, the U.S. could experience a substantial real depreciation over the next 25 years.

The basic message of our paper is that there are many aspects of current account adjustment that are not possible to predict. Under some scenarios that we do not regard as entirely unreasonable, we find that the U.S. current account deficit can be explained as the equilibrium outcome of optimal consumption decisions. But some of our modeling 
simplifications and assumptions might be wrong in important ways, and so it may turn out, as many have been warning, that the deficits have put the U.S. on the path to ruin.

\section{References}

Backus, David; Espen Henriksen; Frederic Lambert; and, Chris Telmer, 2005, “Current Account Fact and Fiction,” working paper, New York University.

Bernanke, Ben, 2005, “The Global Saving Glut and the U.S. Current Account Deficit,” Homer Jones Lecture, St. Louis, Missouri.

Blanchard, Olivier; Francesco Giavazzi; and Filipa Sa, 2004, “The U.S. Current Account and the Dollar,” NBER working paper no. 11137.

Bohn, Henning, 1998, “The Behavior of U.S. Public Debts and Deficits,” Quarterly Journal of Economics 113, 949-963.

Bohn, Henning, 2004, “Are Stationarity and Cointegration Restrictions Necessary for the Intertemporal Budget Constraint?” working paper, UC-Santa Barbara.

Bohn, Henning, 2005, “The Sustainability of Fiscal Policy in the United States,” working paper, UC Santa-Barbara.

Caballero, Ricardo; Emmanuel Farhi; and, Pierre-Olivier Gourinchas, 2005, “An Equilibrium Model of ‘Global Imbalances’ and Low Interest Rates,” working paper, MIT.

Chinn, Menzie, 2005, “Getting Serious about the Twin Deficits,” working paper, University of Wisconsin.

Clarida, Richard; Manuela Goretti; and, Mark Taylor, 2005, “Are There Thresholds of Current Account Adjustment in the G7,” working paper, Columbia University.

Edwards, Sebastian, 2005, “Is the U.S. Current Account Deficit Sustainable? And if Not, How Costly is Adjustment Likely to Be?” NBER working paper no. 11541.

Engel, Charles, 2005, “The U.S. Current Account Deficit: A Re-examination of the Role of Private Saving,” working paper, Reserve Bank of Australia.

Engel, Charles, and John H. Rogers, 2006, “The US Current Account Deficit and the Expected Share of World Output,” NBER working paper no. 11921. 
Engen, Eric, and R. Glenn Hubbard, 2004, “Federal Government Debt and Interest Rates,” NBER Macroeconomics Annual, 2004, 83-138.

Erceg, C.J., Guerrieri, L., Gust, C., 2002. Productivity Growth and the Trade Balance in the 1990s: The Role of Evolving Perceptions. mimeo, Federal Reserve Board.

Faruqee, Hamid; Douglas Laxton; Dirk Muir; and, Paolo Pesenti, 2005, “Smooth Landing or Crash? Model-Based Scenarios of Global Current Account Rebalancing,” working paper, International Monetary Fund.

Gale, William G., and Peter R. Orszag, 2004, "Budget Deficits, National Saving, and Interest Rates,” Brookings Papers on Economic Activity, 2004:2, 101-187.

Glick, Reuven, and Kenneth Rogoff, 1995, “Global versus Country-Specific Productivity Shocks and the Current Account,” Journal of Monetary Economics 35, 159-192.

Gourinchas, Pierre-Olivier, and Helene Rey, 2005, “From World Banker to World Venture Capitalist: The US External Adjustment and the Exorbitant Privilege,” working paper, UC Berkeley.

Kouparitsas, Michael, 2005, “Is the U.S. Current Account Deficit Sustainable?” Chicago Fed Letter, June, no. 215.

Kraay, Aart, and Jaume Ventura, 2005, “The Dot-Com Bubble, the Bush Deficits, and the U.S. Current Account,” NBER working paper no. 11543.

Lane, Philip, and Gian Maria Milesi-Ferretti, 2005, “A Global Perspective on External Positions,” working paper, Trinity College Dublin.

Mitchell, Brian R., 1994, International Historical Statistics.

Obstfeld, Maurice, and Kenneth Rogoff, 2000a, “Perspectives on OECD Capital Market Integration: Implications for U.S. Current Account Adjustment,” in Federal Reserve Bank of Kansas City, Global Economic Integration: Opportunities and Challenges. Obstfeld, Maurice, and Kenneth Rogoff, 2000b, “The Six Major Puzzles in International Macroeconomics: Is There a Common Cause?” in Ben Bernanke and Kenneth Rogoff (eds.), NBER Macroeconomics Annual 2000, Cambridge, MA: MIT Press.

Obstfeld, Maurice, and Kenneth Rogoff, 2004, “The Unsustainable U.S. Current Account Revisited,” working paper, Harvard University.

Obstfeld, Maurice, and Kenneth Rogoff, 2005, “Global Current Account Imbalances and Exchange Rate Adjustments,” working paper, UC Berkeley. 
Parker, Jonathan, 1999, "Spendthrift in America? On Two Decades of Decline in the U.S. Saving Rate,” NBER Macroeconomics Annual, 1999, 317-369.

Rogoff, Kenneth, 1996, “The Purchasing Power Parity Puzzle,” Journal of Economic Literature 34, 647-668.

Ruhl, Kim, 2005, “Solving the Elasticity Puzzle in International Economics,” working paper, University of Texas.

Truman, Edwin, 2005, “Postponing Global Adjustment: An Analysis of the Pending Adjustment of Global Imbalances,” working paper, Institute for International Economics. 
Table 1

Estimation Results for Current-Account Model

Ordinary Least Squares, Annual Data, Alternative Samples

(t-statistics)

$$
\left(\frac{X-M}{G N P}\right)_{t}=a+b\left(\frac{E x t D e b t}{G N P}\right)_{t-1}+\text { Add.Variables }
$$

Estimates of $b$

\begin{tabular}{lccccccc}
\hline & $(1)$ & $(2)$ & $(3)$ & $(4)$ & $(5)$ & $(6)$ & $(7)$ \\
\hline \multirow{2}{*}{$1791-2004$} & -0.032 & -0.033 & & -0.031 & & -0.031 & \\
& $(-3.011)$ & $(-3.006)$ & & $(-2.926)$ & & $(-2.921)$ & \\
$1791-1913$ & 0.165 & 0.165 & & 0.162 & & 0.162 & \\
& $(5.487)$ & $(5.492)$ & & $(5.352)$ & & $(5.348)$ & \\
$1919-2004$ & -0.099 & -0.100 & -0.098 & -0.098 & -0.098 & -0.098 & -0.098 \\
& $(-10.624)$ & $(-10.795)$ & $(-10.716)$ & $(-10.383)$ & $(-10.519)$ & $(-10.560)$ & $(-10.618)$ \\
$1946-2004$ & -0.147 & -0.144 & -0.140 & -0.142 & -0.142 & -0.139 & -0.139 \\
& $(-14.714)$ & $(-13.834)$ & $(-13.380)$ & $(-14.855)$ & $(-14.616)$ & $(-14.088)$ & $(-13.808)$ \\
Add. Variables & None & GshrGap & GshrGap & GNPgap & GNPgap & GshrGap & GshrGap \\
& & & UKGDPgap & & UKGDPgap & GNPgap & GNPgap \\
& & & & & & & UKGDPgap \\
& & & & & & & \\
\hline
\end{tabular}

Notes:

(1) X, M are U.S. merchandise exports and imports, respectively, while GNP is U.S. gross national product; ExtDebt is (minus) the U.S. net international investment position. All regressions run with one lag of the debt-GNP ratio and with contemporaneous values all other variables.

(2) GshrGap = Gshr - GshrHP, where GshrHP is the H-P filter value of Gshr;

(3) GNPgap $=($ GNP - GNP.HP $) / G N P . H$, where gnphp is the log of real GNP after applying HP filter.

(4) UK GDP is available for use only back to the 1919-on sub-periods. 
Table 2; U.S. Share of G-7 GDP

(Forecasted (F) as of December 1993 and ex-post Actual (A))

\begin{tabular}{|c|c|c|c|c|c|c|c|c|c|c|c|c|c|}
\hline & 1993 & 1994 & 1995 & 1996 & 1997 & 1998 & 1999 & 2000 & 2001 & 2002 & 2003 & 2004 & $04 / 93$ \\
\hline F & .404 & .409 & .410 & .410 & .410 & .410 & .411 & .411 & .411 & .411 & .411 & .411 & 1.016 \\
\hline A & .404 & .409 & .410 & .413 & .419 & .426 & .433 & .435 & .434 & .437 & .442 & .447 & 1.106 \\
\hline
\end{tabular}

Table 3; Change in U.S. Share of G-7 GDP at Different Forecast Dates (Forecasted (F) and ex-post Actual (A))

\begin{tabular}{|l|l|l|l|l|l|l|l|l|}
\hline & $2004 / 1993$ & $2004 / 1994$ & $2004 / 1995$ & $2004 / 1996$ & $2004 / 1997$ & $2004 / 1998$ & $2004 / 1999$ & $2004 / 2000$ \\
\hline F & 1.016 & 0.997 & 0.997 & 1.007 & 1.025 & 1.029 & 1.027 & 1.021 \\
\hline A & 1.106 & 1.084 & 1.082 & 1.074 & 1.061 & 1.044 & 1.028 & 1.025 \\
\hline
\end{tabular}

Table 4; U.S. Share of G-7 GDP

(Forecasted as of August 2005)

\begin{tabular}{|l|l|l|l|l|l|l|l|l|l|l|l|l|l|l|}
\hline & 2005 & 2006 & 2007 & 2008 & 2009 & 2010 & 2011 & 2012 & 2013 & 2014 & 2015 & 2016 & 2017 & $2017 / 04$ \\
\hline $\mathrm{F}$ & .452 & .455 & .459 & .462 & .464 & .467 & .470 & .473 & .475 & .478 & .481 & .484 & .487 & 1.089 \\
\hline
\end{tabular}


Figure 1

\section{U.S. Current Account/GDP (Percent)}

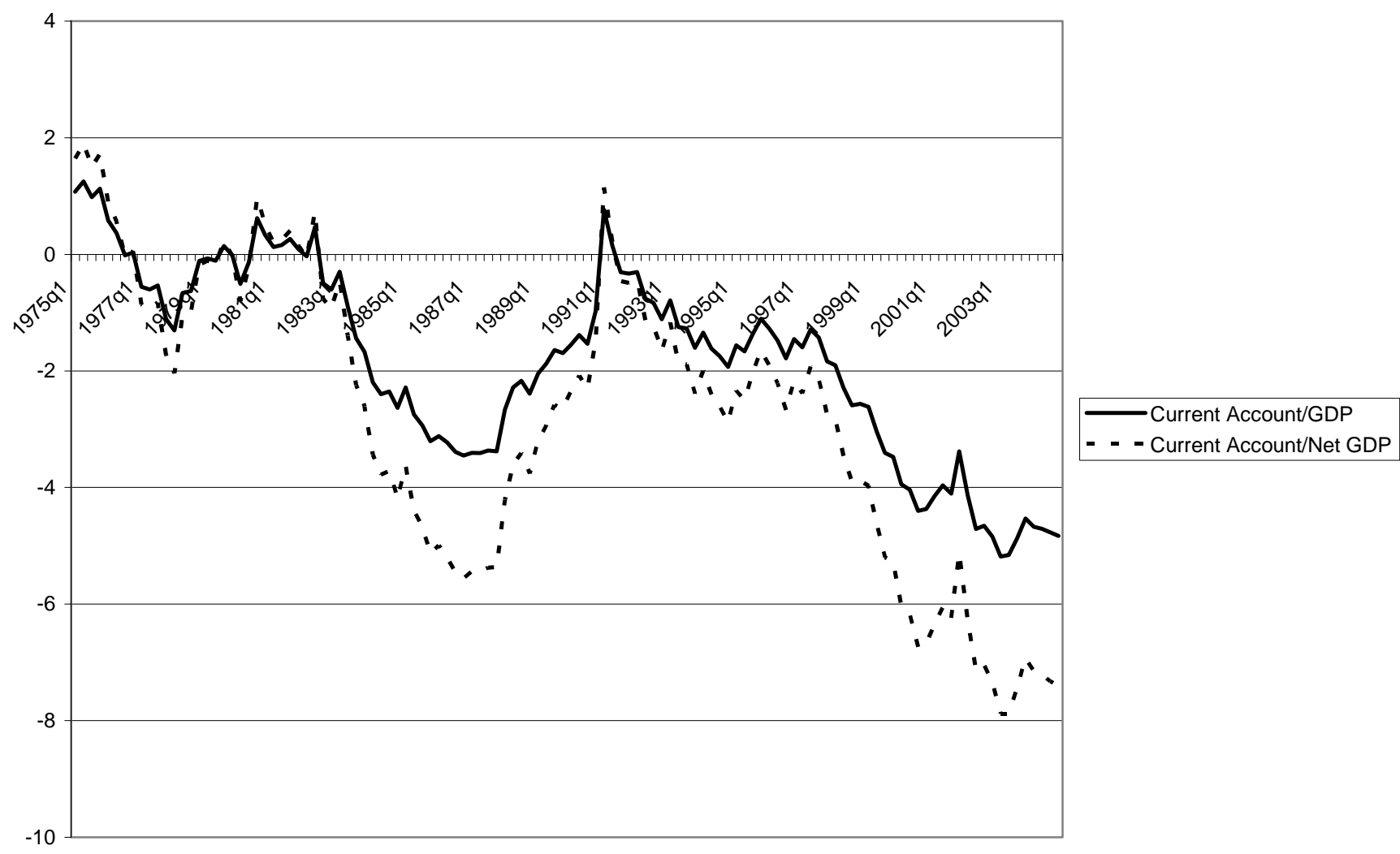


Figure 2

U.S. Share of Advanced Country Net GDP

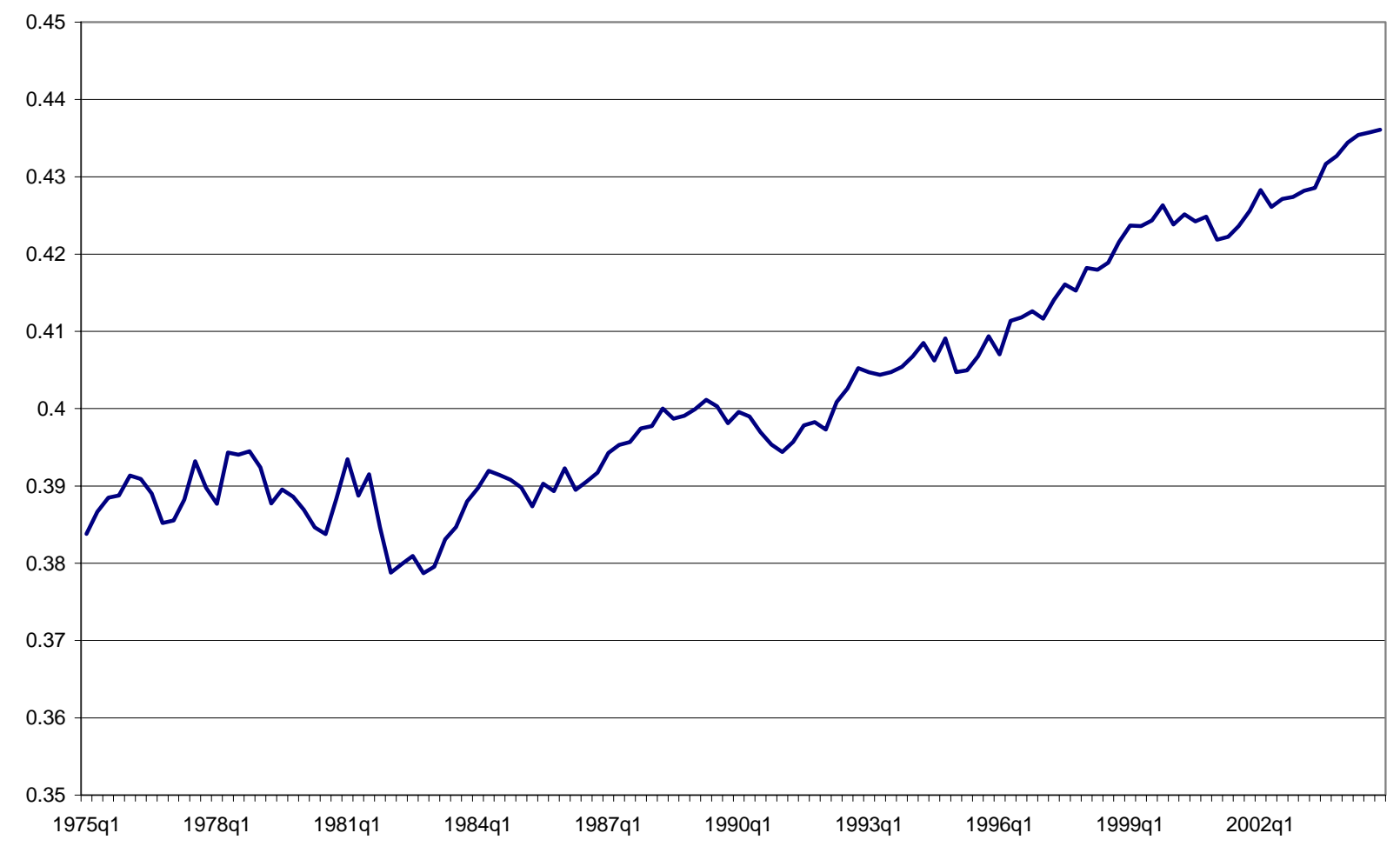

Source: OECD Economic Outlook database 
Figure 3

External Debt and Trade Deficit

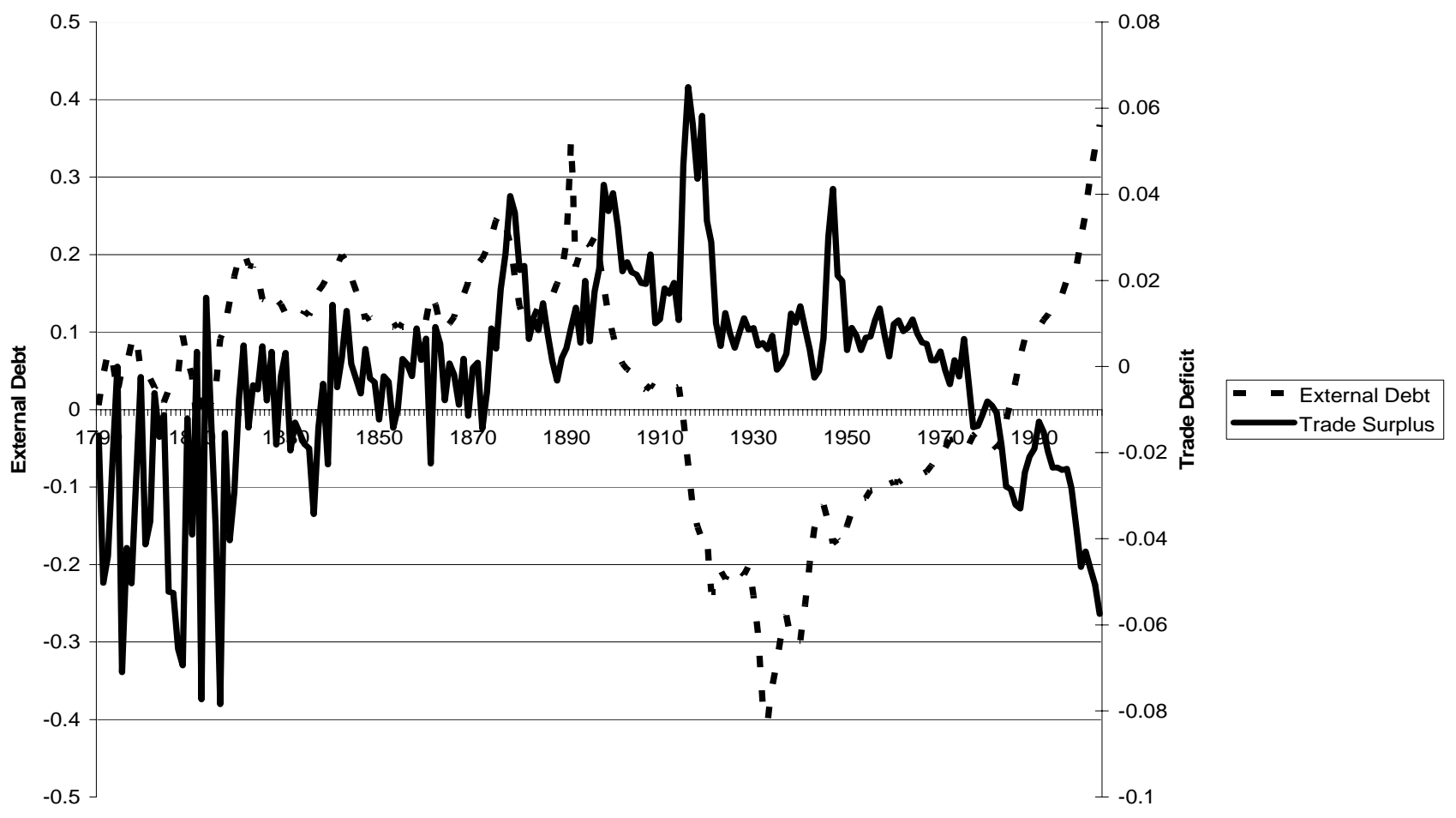

Trade Surplus $=\mathrm{X}-\mathrm{M} / \mathrm{GNP}$

External Debt $=$ NetExtDebtYshr 
Figure 4

U.S. Net International Investment Position

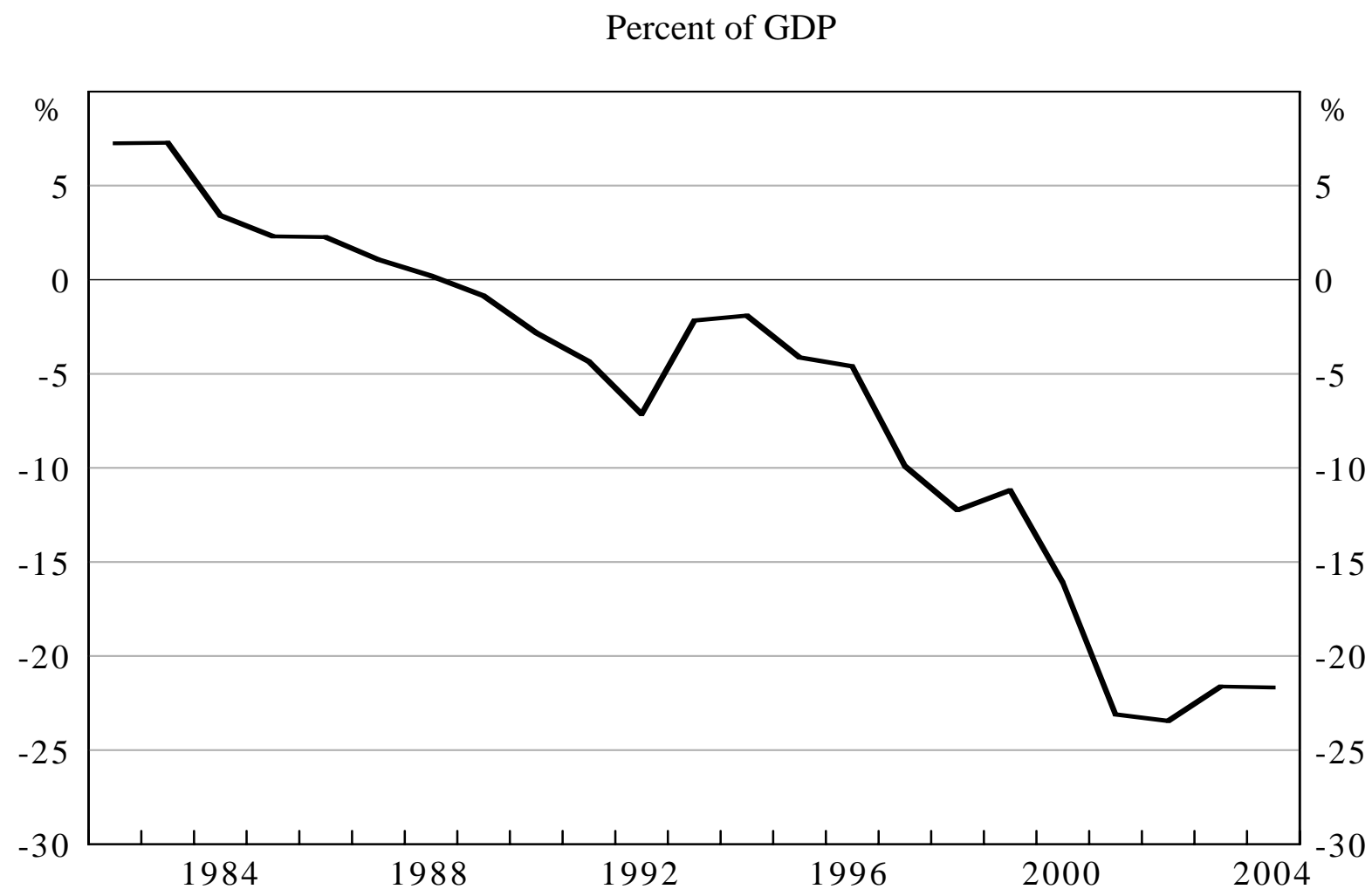

Source: Bureau of Economic Analysis (BEA), International Economic Accounts 
Figure 5

U.S. Net Investment Income

Percent of GDP

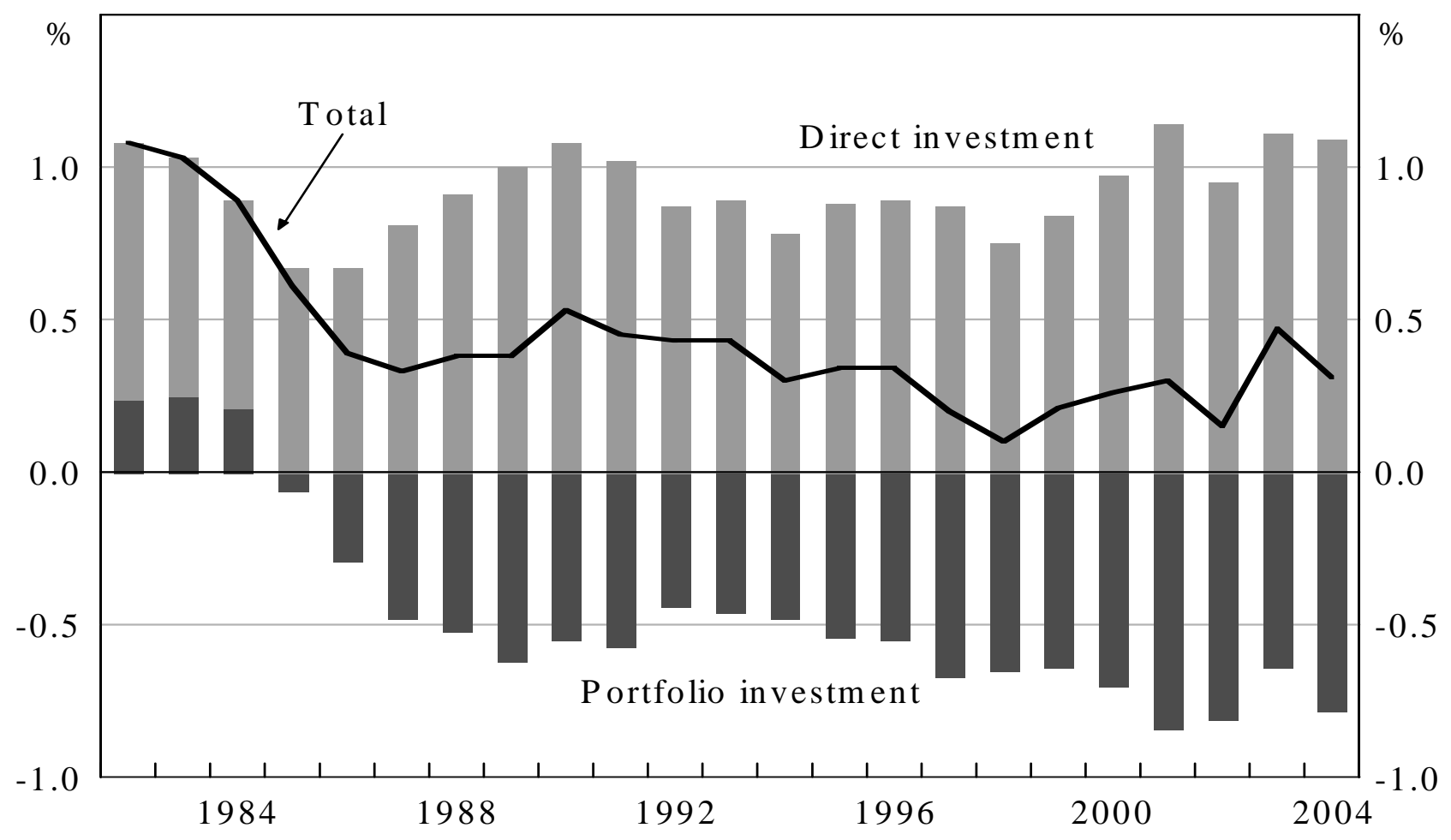

Source: Bureau of Economic Analysis (BEA), International Economic Accounts 
Figure 6

U.S. Current Account as Share of World Net GDP -- Data and Model Fitted Values

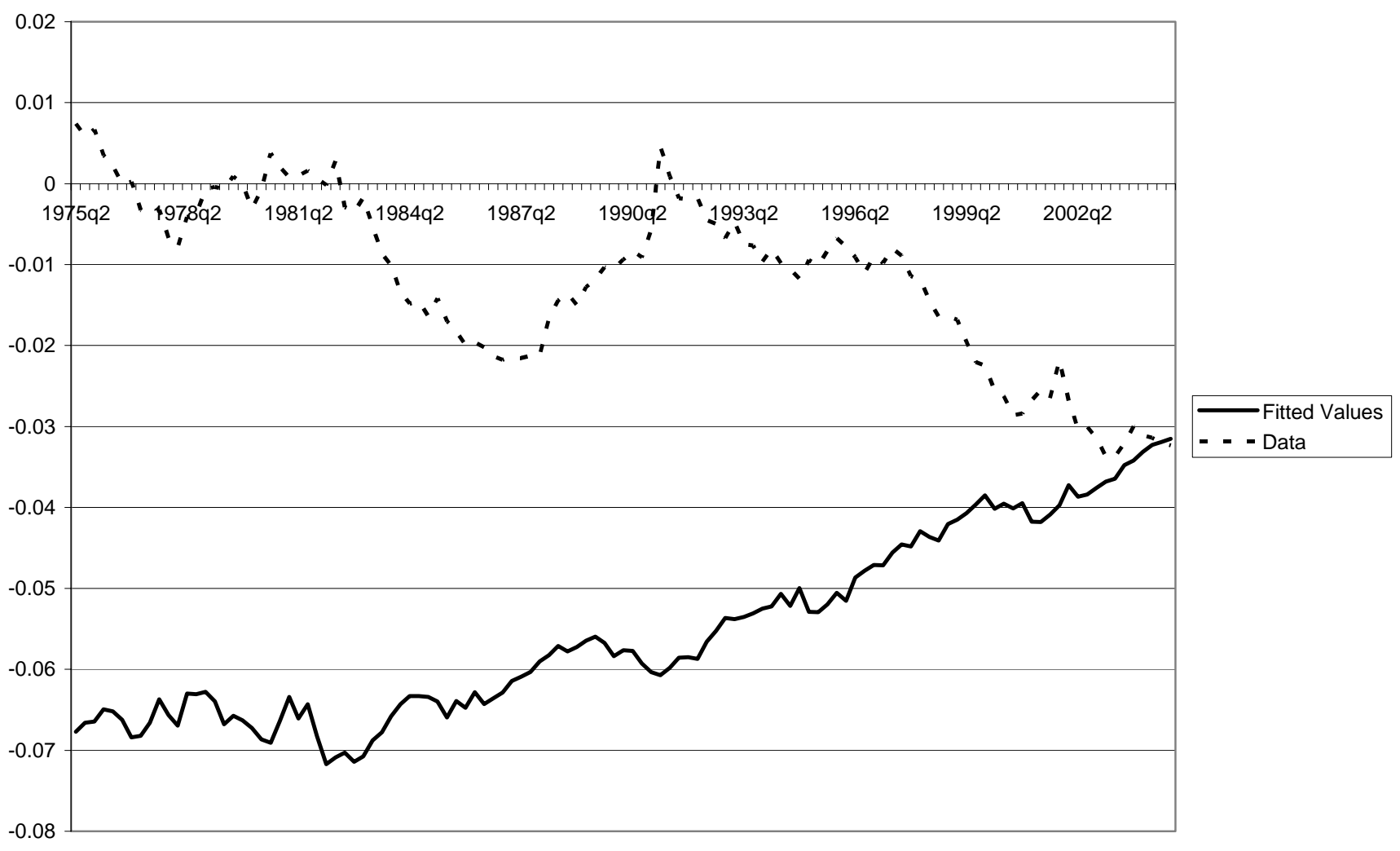




\section{Figure 7}

U.S. Actual and Forecast Shares of G7 GDP

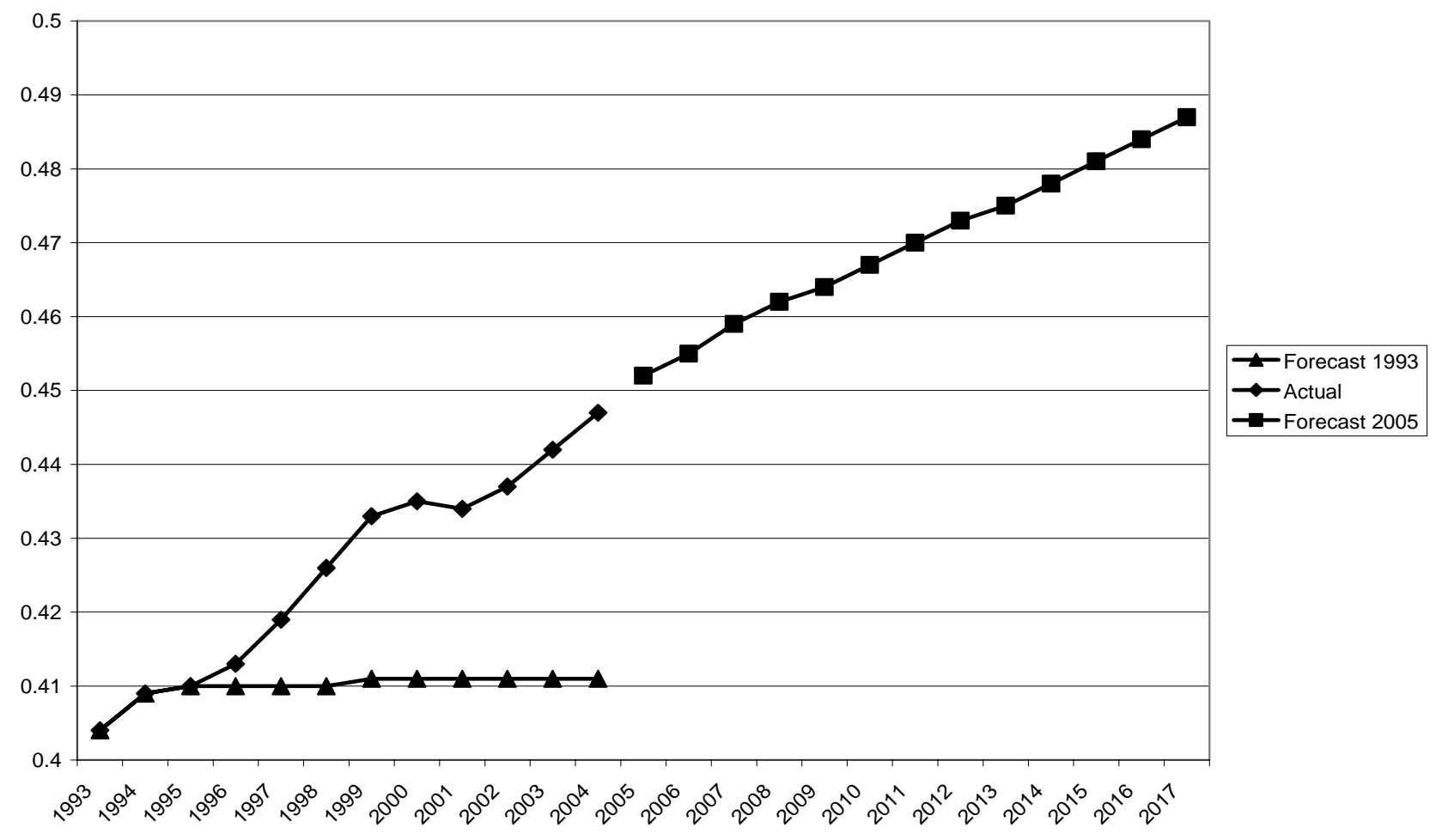




\section{Figure 8}

\section{U.S. Current Account/Net GDP -- Data and Model}

Expectations from Consensus Forecasts

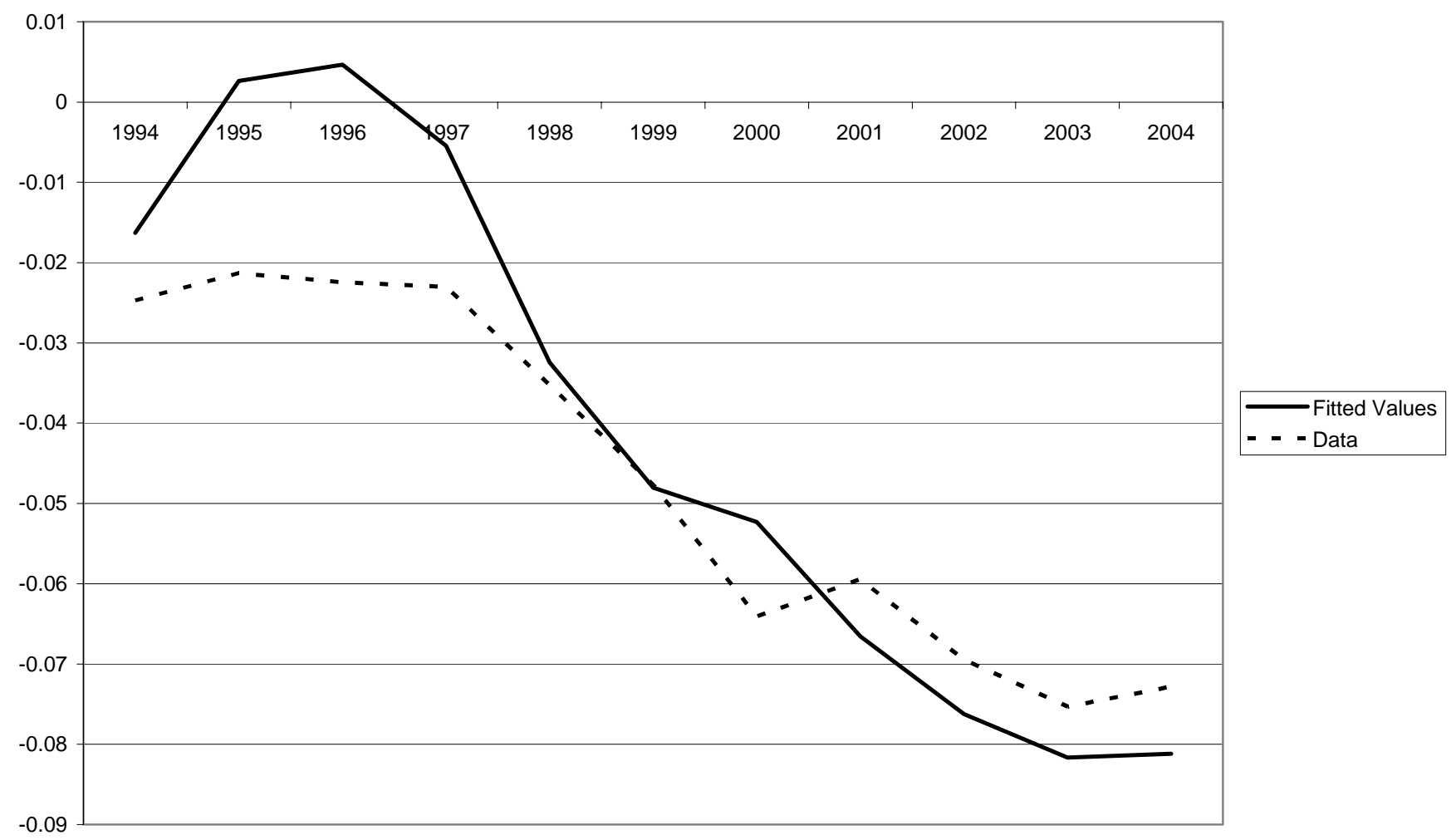

